\title{
Metabolic profiling of Shu-Yu capsule in rat serum based on metabolic fingerprinting analysis using HPLC-ESI-MS ${ }^{\mathbf{n}}$
}

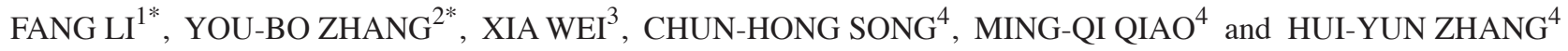 \\ ${ }^{1}$ Hospital Pharmacy, Fengtai Maternal and Children's Health Hospital of Beijing, Beijing 100069; \\ ${ }^{2}$ State Key Laboratory of Natural and Biomimetic Drugs and Department of Natural Medicines, \\ School of Pharmaceutical Sciences, Peking University Health Science Center, Peking University, Beijing 100101; \\ ${ }^{3}$ Department of Pharmacology and Toxicology, Shandong Institute for Food and Drug Control, Jinan, Shandong 250012; \\ ${ }^{4}$ Institute of Traditional Chinese Medicine Theory, School of Basic Medicine, Shandong University \\ of Traditional Chinese Medicine, Jinan, Shandong 100044, P.R. China
}

Received April 19, 2015; Accepted March 7, 2016

DOI: $10.3892 / \mathrm{mmr} .2016 .5082$

\begin{abstract}
The Chinese herbal formula, Shu-Yu capsule (SYC), has been successfully used to treat depression-like disorders in clinical settings. To rapidly identify the chemical constituents of SYC and its metabolites in rat serum, a simple and sensitive liquid chromatography-tandem mass spectrometry method was established in the present study. By comparing the retention times, MS and $\mathrm{MS}^{\mathrm{n}}$ spectra data in the literature and reference standards, a total of 73 compounds were identified from SYC. In rat serum, 62 components, including 13 prototype compounds and 49 metabolites were identified. Of these components, 14 metabolites were confirmed as novel metabolites of SYC. The results of the present study indicated that certain flavonoid glycosides and monoterpene glycosides were absorbed directly. Glucuronidation and sulfation were identified as the predominant metabolic pathways of the components in SYC. In addition, certain phase I reactions, including hydrolysis, demethylation and hydroxylation occurred in the rats. These results provide scientific evidence,
\end{abstract}

Correspondence to: Professor Ming-Qi Qiao or Professor Hui-Yun Zhang, Institute of Traditional Chinese Medicine Theory, School of Basic Medicine, Shandong University of Traditional Chinese Medicine, Changqing University Science and Technology Park, 4655 University Road, Changqing, Jinan, Shandong 100044, P.R. China

E-mail: qmingqi@163.com

E-mail: zhhuiyun@163.com

*Contributed equally

Abbreviations: SYC, Shu-Yu capsule; TCM, traditional Chinese medicine; HPLC-ESI-MS ${ }^{n}$, high performance liquid chromatography-electrospray ionization tandem mass spectrometry

Key words: Shu-Yu capsule, chemical constituents, absorption, high performance liquid chromatography-electrospray ionization tandem mass spectrometry, metabolites which support further investigations of the pharmacology and mechanism of SYC.

\section{Introduction}

The Shu-Yu capsule (SYC) formulation is a four-herb traditional Chinese medicine (TCM) used for the treatment of clinical depression-like disorders, including premenstrual syndrome (1). It is composed of four herbal ingredients: Radix Bupleuri (Bupleurum chinense DC.), Radix Paeoniae Alba (Paeonia lactiflora Pall.), Rhizoma Cyperi (Cyperus rotundus Linn.) and Radix Glycyrrhizae (Glycyrrhiza uralensis Fisch.). According to the TCM formulation theory (2), Radix Bupleuri and Radix Paeoniae Alba are mutually complementary as the monarch herbs of the formula, which represent the components with the major therapeutic roles.

It has been demonstrated that the total glycosides of peony exert significant antidepressant-like effects by increasing the expression levels of brain derived neurotrophic factor and nerve growth factor in selective brain tissues (3). Radix Bupleuri is another monarch ingredient in SYC, which may affect the quality of prescriptions significantly. Bupleuri Radix, or prescriptions containing Bupleuri Radix as the major component, for example Xiaochaihutang, exert antidepressant-like effects by modulating serotonergic and noradrenergic systems in brain regions of rat models of depression $(4,5)$. Our previous studies also revealed antidepressant-like effects of ethanol extracts from Paeonia lactiflora Radix and Bupleuri Radix (6). These findings confirmed that Paeoniae Radix and Bupleuri Radix have effects on the central nervous system. According to the theory of serum pharmacochemistry, only constituents absorbed into blood have the potential to exert pharmacological bioactivities (7). However, the metabolites absorbed in the blood following oral administration of SYC remain to be elucidated.

The present study aimed to confirm the absorbed components and the relative metabolites of SYC, which may be the potential bioactive components in the blood following intragastric administration of SYC. Thus, a reliable high performance liquid chromatography-electrospray ionization tandem mass 
spectrometry (HPLC-ESI-MS ${ }^{n}$ ) system was established for the detection of prototype compounds and metabolites in the rat serum following oral administration of SYC. Screening for potential bioactive components in SYC may assist in future investigations into its mechanism of action at the molecular level.

\section{Materials and methods}

Reagents. Acetonitrile, methanol and glacial acetic acid were of LC/MS reagent grade and purchased from Merck Millipore (Darmstadt, Germany), Ultra-pure water was prepared using a Milli-Q water purification system (EMD Millipore, Bedford, MA, USA). The other solvents were of analytical grade.

Radix Bupleuri, Radix Paeoniae, Radix Glycyrrhizae and Rhizoma Cyperi were collected in Shandong Province (Shandong, China) and were authenticated by Professor Hui Yun Zhang (Shandong University of Traditional Chinese Medicine, Jinan, China). SYCs were manufactured by Qingdao Haichuan Innovative Biological \& Natural Drug Research Institute (Qingdao, China).

The composition and preparation of the SYC were as previously described (1).

Instrument and analysis conditions. The HPLC analysis was performed on an Agilent-1100 series liquid chromatograph system (Agilent Technologies, Inc., Santa Clara, CA, USA), equipped with a binary pump, an auto sampler, a photo-diode array detector and a column temperature controller. The analytical column was a Kromasil C18 100R (5 $\mu \mathrm{m}, 250 \times 4.6 \mathrm{~mm}$ i.d.; AkzoNobel, Bohus, Sweden) and the oven temperature was maintained at $25^{\circ} \mathrm{C}$. A mobile phase, composed of eluent $\mathrm{A}$ (acetonitrile) and $\mathrm{B}(0.2 \%$ acetic acid in water, v/v) with a gradient was used for the separation. The elution conditions were applied with the following linear gradient: $0-5 \mathrm{~min}, 2-5 \% \mathrm{~A} ; 5-12 \mathrm{~min}, 5-12 \% \mathrm{~A} ; 12-28 \mathrm{~min}$, $12-16 \%$ A; $28-42$ min, $16-24 \%$ A; $42-56$ min, $24-36 \%$ A; 56-72 $\mathrm{min}, 36-39 \%$ A; 72-81 min, 39-64\% A; 81-90 min and $64-100 \%$ A. The flow rate was $1.0 \mathrm{ml} / \mathrm{min}$ and peaks were detected at $254 \mathrm{~nm}$.

In the subsequent ESI-MS/MS experiment, an MSD Trap XCT Plus mass spectrometer (Agilent Technologies) was connected to the same HPLC instrument via an electrospray ionization (ESI) interface (Agilent Technologies, Inc.). The HPLC effluent was introduced into the ESI source in a post-column splitting ratio of 1:4. The ESI-MS operating conditions (negative ion) were optimized using the SYC, as follows: Nebulizer gas pressure, 40.00 psi; dry gas flow rate, $11.00 \mathrm{l} / \mathrm{min}$; capillary temperature, $350^{\circ} \mathrm{C}$; electrospray voltage of the ion source, $3,500 \mathrm{~V}$; skimmer of $40.0 \mathrm{~V}$; capillary exit, $121.0 \mathrm{~V}$; compound stability, 50\%; trap drive level, $100 \%$; target mass, $500 \mathrm{~m} / \mathrm{z}$; scan range, $100-14,00 \mathrm{~m} / \mathrm{z}$; collision energy, $1 \mathrm{~V}$. A data-dependent program was used for the HPLC-ESI-MSn analysis, to enable the protonated or deprotonated ions to be selected for further MSn analysis. An Agilent 6300 Series Trap Control workstation (version 6.1; Agilent Technologies, Inc.) was used for data processing.

Preparation of samples for the extract. Sample preparation of the SYC was as follows: A single capsule from each of five batches of SYC were used. The powder-like contents of the capsules were mixed evenly, and $0.3 \mathrm{~g}$ of the mixed powder was weighed. The Radix Paeoniae, Radix Bupleuri, Rhizoma Cyperi and Radix Glycyrrhizae samples were crushed into a homogeneous size separately and sieved through a No. 40 mesh sieve (Jin Yuan Screen Factory, Yangquan, China) for further assessment.

The weighed powder was suspended in $25.0 \mathrm{ml}$ of $70 \%$ (v/v) methanol and extracted in an ultrasonic water bath for $30 \mathrm{~min}$ at room temperature. Each resulting mixture was filtered through $0.22-\mu \mathrm{m}$ membranes prior to use, and a $10-\mu 1$ aliquot was injected into the HPLC-MS system for analysis.

In-vivo experiments. A total of 24 male Wistar rats (weight, 180-220 g; age, 8 weeks) were supplied by the Laboratory Animal Center of Shandong University of Traditional Chinese Medicine. The present study was approved by the Institutional Committee for Animal Care and Use of Shandong University of Traditional Chinese Medicine. The rats were housed in poly cages with free access to food and water, at a temperature of $22-26^{\circ} \mathrm{C}$ and relative humidity of $50-70 \%$. The rats were acclimatized to the environment for 1 week prior to initiating the experiment. All rats were fasted, with free access to water, for $12 \mathrm{~h}$ prior to the experiment. Subsequently, 12 rats were administered with SYC at a dose of $4.1 \mathrm{~g} / \mathrm{kg}$ body weight orally for 3 days, once per day. Another group of 12 rats served as a blank control group, which received physiological saline. On day 4, blood samples were collected from the inferior venae cava, 90 min after intragastric administration of SYC, and centrifuged at $1,500 \times \mathrm{g}$ for $15 \mathrm{~min}$ at $4^{\circ} \mathrm{C}$ to obtain serum samples, which were then frozen and stored at $-80^{\circ} \mathrm{C}$ until analysis. Subsequently, the rats were sacrificed by cervical dislocation. The time points were selected based on our previous pharmacokinetic studies (8). All procedures were in agreement with the National Institute of Health's Guidelines on the Principles of Animal Care (9).

Sample preparation. The dried powders from the SYCs and the four herbs were weighed accurately $(0.3 \mathrm{~g})$, suspended in $25.0 \mathrm{ml}$ of $70 \%(\mathrm{v} / \mathrm{v})$ methanol, and extracted in an ultrasonic water bath (KQ-250E; Kunshan Ultrasonic Instruments Co., Ltd.) for $30 \mathrm{~min}$ at room temperature. Each resulting mixture was filtered through $0.22 \mu$ m polyvinylidene fluoride membranes (Merck Millipore) prior to use, and a $10 \mu \mathrm{l}$ aliquot was injected into the HPLC-MS system for analysis.

Each collected serum sample was thawed and centrifuged at $1,500 \mathrm{x} \mathrm{g}$ for $30 \mathrm{~min}$ at $4^{\circ} \mathrm{C}$. The supernatant $(100 \mu \mathrm{l})$ was then mixed with $300 \mu \mathrm{l}$ methanol and vortexed for $2 \mathrm{~min}$. The denatured protein precipitate was separated by centrifugation at $16,000 \mathrm{x} \mathrm{g}$ for $30 \mathrm{~min}$ at $4^{\circ} \mathrm{C}$, and the supernatant was separated and evaporated to dryness under a gentle nitrogen stream at $37^{\circ} \mathrm{C}$. The residue was reconstituted in $100 \mu \mathrm{l}$ methanol and centrifuged at $16,000 \mathrm{x} \mathrm{g}$ for $30 \mathrm{~min}$ at $4^{\circ} \mathrm{C}$. An aliquot of $20 \mu \mathrm{l}$ of the supernatant was analyzed on the HPLC-MS system.

\section{Results}

HPLC-MS $S^{n}$ analysis of constituents in SYC extract in negative ion mode. Utilizing the optimized LC-MS ${ }^{\mathrm{n}}$ method, the components of the extracts of SYC and its single herbal extracts 
Table I. Identification of the chemical constituents of SYC formula by liquid chromatography-tandem mass spectrometry in negative ion mode.

\begin{tabular}{|c|c|c|c|c|c|c|}
\hline No. & $\mathrm{t}_{\mathrm{R}}^{\mathrm{a}}$ & $\begin{array}{c}{[\mathrm{M}-\mathrm{H}]^{-}} \\
(\mathrm{m} / \mathrm{z})\end{array}$ & $\operatorname{MS}^{\mathrm{n}}(\mathrm{m} / \mathrm{z})$ & Identification & Source & $\begin{array}{l}\text { Molecular } \\
\text { formula }\end{array}$ \\
\hline 1 & 3.1 & 341 & $179,161,143,119,113$ & Caffeic acid-4-O- $\beta$-D-glucopyranoside & RG & $\mathrm{C}_{15} \mathrm{H}_{18} \mathrm{O}_{9}$ \\
\hline $2^{\mathrm{b}}$ & 4.8 & 191 & $111,173,129$ & Quinic acid & RG & $\mathrm{C}_{7} \mathrm{H}_{12} \mathrm{O}_{6}$ \\
\hline $3^{\mathrm{b}}$ & 6.9 & 375 & 345,165 & Desbenzoylpaeoniflorin & $\mathrm{RP}$ & $\mathrm{C}_{16} \mathrm{H}_{24} \mathrm{O}_{10}$ \\
\hline 4 & 9.3 & 169 & 125 & Gallic acid & $\mathrm{RP}$ & $\mathrm{C}_{7} \mathrm{H}_{6} \mathrm{O}_{5}$ \\
\hline 5 & 11.1 & 493 & $313,331,283,169$ & 1'-O-galloyl-sucrose & $\mathrm{RP}$ & $\mathrm{C}_{19} \mathrm{H}_{26} \mathrm{O}_{15}$ \\
\hline 6 & 11.6 & 493 & $313,331,169$ & 6'-O-galloyl-sucrose & $\mathrm{RP}$ & $\mathrm{C}_{19} \mathrm{H}_{26} \mathrm{O}_{15}$ \\
\hline $7^{\mathrm{b}}$ & 15.0 & 527 & $497,479,271$ & 6'-O-galloyldesbenzoylpaeoniflorin & $\mathrm{RP}$ & $\mathrm{C}_{23} \mathrm{H}_{28} \mathrm{O}_{14}$ \\
\hline 8 & 15.8 & 705 & $543,421,375$ & Isomaltopaeoniflorin sulfonate & $\mathrm{RP}$ & $\mathrm{C}_{29} \mathrm{H}_{38} \mathrm{O}_{18} \mathrm{~S}$ \\
\hline $9^{b}$ & 16.5 & 543 & $421,375,259,497$ & Paeoniflorin sulfonate & $\mathrm{RP}$ & $\mathrm{C}_{23} \mathrm{H}_{28} \mathrm{O}_{13} \mathrm{~S}$ \\
\hline 10 & 16.8 & 495 & $465,311,137$ & Oxypaeoniflorin & $\mathrm{RP}$ & $\mathrm{C}_{23} \mathrm{H}_{28} \mathrm{O}_{12}$ \\
\hline 11 & 17.9 & 495 & $465,333,137$ & Oxypaeoniflorin or isomer & $\mathrm{RP}$ & $\mathrm{C}_{23} \mathrm{H}_{28} \mathrm{O}_{12}$ \\
\hline 12 & 19.4 & 525 & $495,167,465,509$ & Mudanpioside E & $\mathrm{RP}$ & $\mathrm{C}_{24} \mathrm{H}_{30} \mathrm{O}_{13}$ \\
\hline 13 & 21.4 & $701^{\mathrm{e}}$ & $641,519,611,489$ & Isomaltopaeoniflorin & $\mathrm{RP}$ & $\mathrm{C}_{29} \mathrm{H}_{38} \mathrm{O}_{16}$ \\
\hline 14 & 23.2 & 641 & $519,489,475,611$ & 6'-O-d-glucopyranosylalbiflorin & $\mathrm{RP}$ & $\mathrm{C}_{29} \mathrm{H}_{18} \mathrm{O}_{16}$ \\
\hline 15 & 24.3 & $701^{\mathrm{e}}$ & $\begin{array}{l}611,593,641,489 \\
471\end{array}$ & Isomaltopaeoniflorin & $\mathrm{RP}$ & $\mathrm{C}_{29} \mathrm{H}_{38} \mathrm{O}_{16}$ \\
\hline $16^{\mathrm{b}, \mathrm{c}}$ & 24.7 & $539^{e}$ & $479,357,327,283$ & Albiflorin & $\mathrm{RP}$ & $\mathrm{C}_{23} \mathrm{H}_{28} \mathrm{O}_{11}$ \\
\hline 17 & 27.6 & 495 & $465,311,137$ & Ortho-Oxypaeoniflorin & $\mathrm{RP}$ & $\mathrm{C}_{23} \mathrm{H}_{28} \mathrm{O}_{12}$ \\
\hline $18^{\mathrm{b}, \mathrm{c}, \mathrm{d}}$ & 27.8 & $539^{e}$ & $479,449,327,165$ & Paeoniflorin & $\mathrm{RP}$ & $\mathrm{C}_{23} \mathrm{H}_{28} \mathrm{O}_{11}$ \\
\hline 19 & 28.7 & $539^{\mathrm{e}}$ & $449,479,327,165$ & Paeoniflorin isomer & $\mathrm{RP}$ & $\mathrm{C}_{23} \mathrm{H}_{28} \mathrm{O}_{11}$ \\
\hline 20 & 33.9 & 787 & $635,483,465,617,313$ & Tetragalloylglucose & $\mathrm{RP}$ & $\mathrm{C}_{34} \mathrm{H}_{28} \mathrm{O}_{22}$ \\
\hline 21 & 34.5 & 787 & $635,465,483,617,313$ & Tetragalloylglucose or isomer & $\mathrm{RP}$ & $\mathrm{C}_{34} \mathrm{H}_{28} \mathrm{O}_{22}$ \\
\hline 22 & 34.7 & 577 & $457,503,383$ & Isoviolanthin & RG & $\mathrm{C}_{27} \mathrm{H}_{30} \mathrm{O}_{14}$ \\
\hline $23^{\mathrm{b}}$ & 35.2 & 549 & $255,417,135,429$ & Liquiritin apioside & RG & $\mathrm{C}_{26} \mathrm{H}_{30} \mathrm{O}_{13}$ \\
\hline 24 & 35.3 & 417 & $255,135,153,119$ & Neoliquiritin & $\mathrm{RG}$ & $\mathrm{C}_{21} \mathrm{H}_{22} \mathrm{O}_{9}$ \\
\hline $25^{\mathrm{b}}$ & 35.7 & 453 & $417,135,255$ & Hydrated Liquiritin & RG & $\mathrm{C}_{21} \mathrm{H}_{26} \mathrm{O}_{11}$ \\
\hline $26^{\mathrm{b}}$ & 35.9 & 417 & $255,135,153,119$ & Liquiritin & RG & $\mathrm{C}_{21} \mathrm{H}_{22} \mathrm{O}_{9}$ \\
\hline 27 & 36.5 & $539^{e}$ & $479,357,327,449$ & Albiflorin or isomer & $\mathrm{RP}$ & $\mathrm{C}_{23} \mathrm{H}_{28} \mathrm{O}_{11}$ \\
\hline $28^{\mathrm{b}}$ & 39.0 & 631 & $613,491,479,465,313$ & Galloyl paeoniflorin/Galloylalbiflorin & $\mathrm{RP}$ & $\mathrm{C}_{30} \mathrm{H}_{32} \mathrm{O}_{15}$ \\
\hline 29 & 39.5 & 939 & $769,617,447,601,599$ & Pentagalloylglucose & $\mathrm{RP}$ & $\mathrm{C}_{41} \mathrm{H}_{32} \mathrm{O}_{26}$ \\
\hline $30^{\mathrm{b}}$ & 42.0 & 631 & $313,509,465,169$ & Galloylpaeoniflorin/Galloylalbiflorin & $\mathrm{RP}$ & $\mathrm{C}_{30} \mathrm{H}_{32} \mathrm{O}_{15}$ \\
\hline 31 & 44.0 & 433 & 271,151 & Naringenin-O-glucose & RG & $\mathrm{C}_{21} \mathrm{H}_{22} \mathrm{O}_{10}$ \\
\hline 32 & 45.3 & 479 & 357,327 & Isopaeoniflorin/Albiflorin $\mathrm{R}_{1}$ & $\mathrm{RP}$ & $\mathrm{C}_{23} \mathrm{H}_{28} \mathrm{O}_{11}$ \\
\hline 33 & 45.7 & 479 & $357,397,327,283,337$ & Isopaeoniflorin/Albiflorin $\mathrm{R}_{1}$ & $\mathrm{RP}$ & $\mathrm{C}_{23} \mathrm{H}_{28} \mathrm{O}_{11}$ \\
\hline 34 & 46.1 & 647 & 525,479 & Benzoylpaeoniflorin sulfonate & $\mathrm{RP}$ & $\mathrm{C}_{30} \mathrm{H}_{32} \mathrm{O}_{14} \mathrm{~S}$ \\
\hline 35 & 46.6 & 647 & 525,479 & Benzoylpaeoniflorin Sulfonate or isomer & $\mathrm{RP}$ & $\mathrm{C}_{30} \mathrm{H}_{32} \mathrm{O}_{14} \mathrm{~S}$ \\
\hline 36 & 47.1 & 549 & $255,417,429,135$ & Isoliquiritin apioside & RG & $\mathrm{C}_{26} \mathrm{H}_{30} \mathrm{O}_{13}$ \\
\hline $37^{\mathrm{b}}$ & 47.6 & 445 & 269,251 & Apigenin-7-O- $\beta$-D-glucuronide & $\mathrm{RB}$ & $\mathrm{C}_{21} \mathrm{H}_{18} \mathrm{O}_{11}$ \\
\hline 38 & 48.0 & 445 & 269,175 & Baicalin & $\mathrm{RB}$ & $\mathrm{C}_{21} \mathrm{H}_{18} \mathrm{O}_{11}$ \\
\hline 39 & 48.2 & 631 & $465,509,313,613,169$ & Galloylpaeoniflorin or isomer & $\mathrm{RP}$ & $\mathrm{C}_{30} \mathrm{H}_{32} \mathrm{O}_{15}$ \\
\hline 40 & 48.5 & 417 & $255,135,153,119$ & Isoliquiritin & RG & $\mathrm{C}_{21} \mathrm{H}_{22} \mathrm{O}_{9}$ \\
\hline 41 & 48.9 & 417 & $255,135,119,153$ & Neoisoliquiritin & RG & $\mathrm{C}_{21} \mathrm{H}_{22} \mathrm{O}_{9}$ \\
\hline 42 & 49.6 & 647 & 617,525 & Benzoylpaeoniflorin Sulfonate/isomer & $\mathrm{RP}$ & $\mathrm{C}_{30} \mathrm{H}_{32} \mathrm{O}_{14} \mathrm{~S}$ \\
\hline 43 & 49.5 & 417 & $255,135,119,153$ & Neoisoliquiritin/isomer & RG & $\mathrm{C}_{21} \mathrm{H}_{22} \mathrm{O}_{9}$ \\
\hline 44 & 49.7 & 255 & $135,153,119$ & Liquiritigenin & RG & $\mathrm{C}_{15} \mathrm{H}_{12} \mathrm{O}_{4}$ \\
\hline 45 & 50.0 & 695 & $549,531,255$ & Licorice-glycoside B & RG & $\mathrm{C}_{35} \mathrm{H}_{36} \mathrm{O}_{15}$ \\
\hline 46 & 50.2 & 725 & $549,531,255$ & Licorice-glycoside A & $\mathrm{RG}$ & $\mathrm{C}_{36} \mathrm{H}_{38} \mathrm{O}_{16}$ \\
\hline 47 & 50.6 & 285 & 269 & Kaempferol & $\mathrm{RB}$ & $\mathrm{C}_{15} \mathrm{H}_{10} \mathrm{O}_{6}$ \\
\hline 48 & 52.1 & 255 & $135,153,119$ & Liquiritigenin/isomer & $\mathrm{RG}$ & $\mathrm{C}_{15} \mathrm{H}_{12} \mathrm{O}_{4}$ \\
\hline 49 & 52.3 & 459 & $283,268,175$ & Wogonoside & RB & $\mathrm{C}_{22} \mathrm{H}_{20} \mathrm{O}_{11}$ \\
\hline
\end{tabular}


Table I. Continued.

\begin{tabular}{|c|c|c|c|c|c|c|}
\hline No. & $\mathrm{t}_{\mathrm{R}}^{\mathrm{a}}$ & $\begin{array}{l}{[\mathrm{M}-\mathrm{H}]^{-}} \\
(\mathrm{m} / \mathrm{z})\end{array}$ & $\operatorname{MS}^{\mathrm{n}}(\mathrm{m} / \mathrm{z})$ & Identification & Source & $\begin{array}{c}\text { Molecular } \\
\text { formula }\end{array}$ \\
\hline $50^{\mathrm{b}}$ & 54.4 & 459 & 283,268 & Wogonoside/isomer & $\mathrm{RB}$ & $\mathrm{C}_{22} \mathrm{H}_{20} \mathrm{O}_{11}$ \\
\hline 51 & 54.8 & $521^{\mathrm{e}}$ & $461,163,265$ & Lactiflorin & $\mathrm{RP}$ & $\mathrm{C}_{23} \mathrm{H}_{26} \mathrm{O}_{10}$ \\
\hline 52 & 55.3 & $521^{\mathrm{e}}$ & 461,163 & Lactiflorin/isomer & $\mathrm{RP}$ & $\mathrm{C}_{23} \mathrm{H}_{26} \mathrm{O}_{10}$ \\
\hline 53 & 57.5 & $643^{e}$ & $583,553,431,165$ & Benzoylpaeoniflorin & $\mathrm{RP}$ & $\mathrm{C}_{30} \mathrm{H}_{32} \mathrm{O}_{12}$ \\
\hline \multirow[t]{2}{*}{54} & 57.6 & 553 & 431,165 & Dehydroxylate Demethylene & & \\
\hline & & & & Benzoylpaeoniflorin & $\mathrm{RP}$ & $\mathrm{C}_{29} \mathrm{H}_{30} \mathrm{O}_{11}$ \\
\hline 55 & 58.4 & $643^{e}$ & $583,461,553$ & Isobenzoylpaeoniflorin & $\mathrm{RP}$ & $\mathrm{C}_{30} \mathrm{H}_{32} \mathrm{O}_{12}$ \\
\hline 56 & 59.2 & 271 & 151,119 & Naringenin & RG & $\mathrm{C}_{15} \mathrm{H}_{12} \mathrm{O}_{5}$ \\
\hline 57 & 61.5 & 837 & $351,193,661,819$ & Licorice-saponin G2 & $\mathrm{RG}$ & $\mathrm{C}_{42} \mathrm{H}_{62} \mathrm{O}_{17}$ \\
\hline 58 & 62.1 & 819 & $351,193,643,801$ & Licorice-saponin $\mathrm{E}_{2}$ & RG & $\mathrm{C}_{42} \mathrm{H}_{60} \mathrm{O}_{16}$ \\
\hline 59 & 65.1 & 255 & $135,153,119$ & Isoliquiritigenin & $\mathrm{RG}$ & $\mathrm{C}_{15} \mathrm{H}_{12} \mathrm{O}_{4}$ \\
\hline 60 & 65.4 & 811 & $649,471,439$ & $\mathrm{SSb}_{3}$ or $\mathrm{SSb}_{4}$ & $\mathrm{RB}$ & $\mathrm{C}_{43} \mathrm{H}_{72} \mathrm{O}_{14}$ \\
\hline 61 & 65.5 & 821 & $645,469,351,193$ & Glycyrrhizin & RG & $\mathrm{C}_{42} \mathrm{H}_{62} \mathrm{O}_{16}$ \\
\hline 62 & 66.3 & 821 & $645,351,193$ & Uralsaponin A & $\mathrm{RG}$ & $\mathrm{C}_{42} \mathrm{H}_{62} \mathrm{O}_{16}$ \\
\hline 63 & 66.8 & 267 & 252 & Formononetin & RG & $\mathrm{C}_{16} \mathrm{H}_{12} \mathrm{O}_{4}$ \\
\hline $64^{\mathrm{d}}$ & 71.9 & 779 & $617,471,541,439,423$ & $\mathrm{SSa}$ & $\mathrm{RB}$ & $\mathrm{C}_{42} \mathrm{H}_{68} \mathrm{O}_{13}$ \\
\hline $65^{\mathrm{d}}$ & 72.4 & 779 & $617,471,541,439$ & $\mathrm{SSd}$ & $\mathrm{RB}$ & $\mathrm{C}_{42} \mathrm{H}_{68} \mathrm{O}_{13}$ \\
\hline 66 & 72.7 & 367 & $309,297,352$ & Glycycoumarin & $\mathrm{RG}$ & $\mathrm{C}_{21} \mathrm{H}_{20} \mathrm{O}_{6}$ \\
\hline 67 & 76.5 & 283 & 268 & Wogonin & $\mathrm{RB}$ & $\mathrm{C}_{16} \mathrm{H}_{12} \mathrm{O}_{5}$ \\
\hline 68 & 77.3 & $677^{\mathrm{e}}$ & $617,471,541,439$ & Prosaikogenin G/F & $\mathrm{RB}$ & $\mathrm{C}_{36} \mathrm{H}_{58} \mathrm{O}_{8}$ \\
\hline 69 & 77.7 & $677^{\mathrm{e}}$ & $617,471,541,407$ & Prosaikogenin A/D & $\mathrm{RB}$ & $\mathrm{C}_{36} \mathrm{H}_{58} \mathrm{O}_{8}$ \\
\hline 70 & 80.4 & 367 & $309,281,297,265$ & Glycycoumarin/isomer & $\mathrm{RG}$ & $\mathrm{C}_{21} \mathrm{H}_{20} \mathrm{O}_{6}$ \\
\hline 71 & 82.0 & 353 & 297 & Licoisoflavone A & RG & $\mathrm{C}_{20} \mathrm{H}_{18} \mathrm{O}_{6}$ \\
\hline 72 & 83.0 & 353 & 297 & Licoisoflavone $\mathrm{A} /$ isomer & RG & $\mathrm{C}_{20} \mathrm{H}_{18} \mathrm{O}_{6}$ \\
\hline 73 & 83.3 & 381 & 366 & licoricone & $\mathrm{RG}$ & $\mathrm{C}_{22} \mathrm{H}_{22} \mathrm{O}_{6}$ \\
\hline
\end{tabular}

${ }^{a} t_{R}$, retention time; ${ }^{b}$ absorbed compounds detected in dosed rat serum; ${ }^{c}$ absorbed compounds detected in dosed rat brain; ${ }^{\mathrm{d} i d e n t i f i e d ~ b y ~ c o m-~}$ parison with standards; ${ }^{\text {es }}$ solvent adduct ion $\left[\mathrm{M}-\mathrm{H}+\mathrm{CH}_{3} \mathrm{COOH}\right]-$; RP, radix paeoniae alba; $\mathrm{RG}$, radix glycyrrhizae; RB, radix bupleuri. SS, saikosaponin; MS, mass spectrometry.

(Radix Paeoniae Alba, Radix Bupleuri, Radix Glycyrrhizae and Rhizoma Cyperi) were identified.

By comparing the $\mathrm{MS}^{\mathrm{n}}$ spectra data with the reference standards and literature data, 73 components, including flavonoids, terpenes and phenolic acids, were identified in the SYC extract. Among these 73 components, three predominant compounds were confirmed using reference standards. The HPLC-MS $^{\mathrm{n}}$ data of the 73 tentatively identified components are summarized in Table I.

By comparing the chromatograms and $\mathrm{MS}^{\mathrm{n}}$ data between the extracts of SYC and the single herb extracts, the 73 identified components originated predominantly from Radix Bupleuri, Radix Paeoniae Alba and Radix Glycyrrhizae. In the SYC extracts, 34 compounds belonging to monoterpene glycosides, galloylglucoses and phenolic compounds were identified as being derived from Radix Paeoniae. In addition, 11 compounds belonging to flavonoids and triterpene glycosides were identified as ingredients of Radix Bupleuri, and 28 compounds were derived from Radix Glycyrrhizae. The identity of each component was confirmed by matching the empirical molecular formula with that of previously published information, and was further elucidated using multistage mass spectrometry, particularly for the unmatchable components in the in-house library. In addition, certain data, including retention time (tR), were also included as complementary data for identification. Acetic acid was added to the mobile phase as a modifier, and its adduct ions $\left[\mathrm{M}-\mathrm{H}+\mathrm{CH}_{3} \mathrm{COOH}\right]^{-}$were be observed in the mass spectra of certain components.

Identification of the components of SYC from Radix Paeoniae. In the present study, a total of 34 compounds were identified in the extracts of SYC from Radix Paeoniae. For compound $16(\mathrm{tR}=24.7 \mathrm{~min})$, the solvent adduct ion $\left[\mathrm{M}-\mathrm{H}+\mathrm{CH}_{3} \mathrm{COOH}\right]^{-}$ at $539 \mathrm{~m} / \mathrm{z}$ was observed, and the featured fragmentation ions at 283, 327, 357 and $479 \mathrm{~m} / \mathrm{z}$ were produced, consistent with the data reported in the literature (10). Compound 18 $(\mathrm{tR}=27.8 \mathrm{~min}$ ) was identified as paeoniflorin by comparison with reference compounds, and produced the featured fragmentation ions at 165,327 and $449 \mathrm{~m} / \mathrm{z}$, consistent with the data reported in the literature (10). Compounds 19 (tR=28.7 min) and 27 ( $\mathrm{tR}=36.5 \mathrm{~min}$ ) were induced as an isomer of albiflorin and paeoniflorin, respectively, due to a series of common characteristic ions (Table I). Compounds 32 (tR=45.3 min) and 33 ( $\mathrm{tR}=45.7 \mathrm{~min})$ were identified as isopaeoniflorin 
and albiflorin $\mathrm{R}_{1}$, sharing the molecular formula $\mathrm{C}_{23} \mathrm{H}_{28} \mathrm{O}_{11}$, according to literature references (11). Compounds 10 $(\mathrm{tR}=16.8 \mathrm{~min}), 11(\mathrm{tR}=17.9 \mathrm{~min})$ and $17(\mathrm{t} R=27.6 \mathrm{~min})$ were deduced as oxypaeoniflorin/oxypaeoniflorin isomer and ortho-oxypaeoniflorin (10), respectively, considering that oxypaeoniflorin exhibits a higher polarity than ortho-oxypaeoniflorin; and their ions in common at $495 \mathrm{~m} / \mathrm{z}$, $465 \mathrm{~m} / \mathrm{z}\left(\left[\mathrm{M}-\mathrm{H}-\mathrm{HCHO}^{-}\right)\right.$and $137 \mathrm{~m} / \mathrm{z}\left(\left[\mathrm{C}_{7} \mathrm{H}_{5} \mathrm{O}_{3}\right]^{-}\right)$. Compound 12 (tR=19.4 min) gave $[\mathrm{M}-\mathrm{H}]^{-}$ions at $\mathrm{m} / \mathrm{z} 525\left(\mathrm{C}_{24} \mathrm{H}_{30} \mathrm{O}_{13}\right)$ and further produced an $\left[\mathrm{M}-\mathrm{H}-\mathrm{OCH}_{3}\right]^{-}$ion at $495 \mathrm{~m} / \mathrm{z}$ and an $\left[\mathrm{M}-\mathrm{H}-\mathrm{OCH}_{3}-\mathrm{CH}_{2} \mathrm{OH}\right]^{-}$ion at $465 \mathrm{~m} / \mathrm{z}$. Therefore, this species was tentatively identified as mudanpioside $\mathrm{E}$, according to its structure reported in the literature (12).

The two isomer compounds, 51 ( $\mathrm{tR}=54.8 \mathrm{~min})$ and 52 ( $\mathrm{tR}=55.3 \mathrm{~min})(13)$, revealed the solvent adduct ion $\left[\mathrm{M}-\mathrm{H}+\mathrm{CH}_{3} \mathrm{COOH}\right]^{-}$at $521 \mathrm{~m} / \mathrm{z}$, the protonated molecular ion $[\mathrm{M}-\mathrm{H}]^{-}$at $461 \mathrm{~m} / \mathrm{z}$ and the ion at $265 \mathrm{~m} / \mathrm{z}$, which was produced via the neutral losses of $\mathrm{CO}_{2}(44 \mathrm{Da}), \mathrm{HCHO}(30 \mathrm{Da})$ and benzoyl acid (BA, $122 \mathrm{Da}$ ) from the precursor ion. Therefore, compound 51,52 was tentatively identified as lactiflorin or an isomer.

Compounds $53(\mathrm{tR}=57.5 \mathrm{~min})$ and $55(\mathrm{tR}=58.4 \mathrm{~min})$ were tentatively assigned as benzoylpaeoniflorin and isobenzoylpaeoniflorin (11) by the solvent adduct ion $\left[\mathrm{M}-\mathrm{H}+\mathrm{CH}_{3} \mathrm{COOH}\right]^{-}$at $643 \mathrm{~m} / \mathrm{z}$ and the protonated molecular ion $[\mathrm{M}-\mathrm{H}]^{-}$at $583 \mathrm{~m} / \mathrm{z}$, which further loses a benzoyl group (122 Da) to produce the ion [M-H-122] at $461 \mathrm{~m} / \mathrm{z}$ and at $553 \mathrm{~m} / \mathrm{z}$, and further loses a benzoyl group (122 Da) to produce the ion [M-H-HCHO-122] at $431 \mathrm{~m} / \mathrm{z}$. Compound 54 may be the secondary product of benzoylpaeoniflorin in the plant due to the same $[\mathrm{M}-\mathrm{H}]^{-}$at 553,431 and $165 \mathrm{~m} / \mathrm{z}$ as compound 55 . Therefore, compound 54 was identified as dehydroxylate demethylene benzoylpaeoniflorin.

Compound $3(\mathrm{tR}=6.9 \mathrm{~min})$ exhibited the $[\mathrm{M}-\mathrm{H}]^{-}$ion at $375 \mathrm{~m} / \mathrm{z}$, and then produced the ion [M-H-HCHO $]^{-}$at $345 \mathrm{~m} / \mathrm{z}$ in the negative full scan mode. A further fragment at $165 \mathrm{~m} / \mathrm{z}$ suggested the existence of a glucosyl group. Therefore, compound 3 was tentatively identified as desbenzoylpaeoniflorin, according to the literature and its fragmentation pathway (10). Compound 7 (tR=15.0 min) produced the ion $[\mathrm{M}-\mathrm{H}]^{-}$at $527 \mathrm{~m} / \mathrm{z}$ in the MS spectrum and product ion [M-H-HCHO $]^{-}$at $497 \mathrm{~m} / \mathrm{z}$ in the MS/MS spectrum. The $\mathrm{MS}^{3}$ spectral ions at $479 \mathrm{~m} / \mathrm{z}\left(\left[\mathrm{M}-\mathrm{H}-\mathrm{HCHO}-\mathrm{H}_{2} \mathrm{O}\right]^{-}\right)$ and $271 \mathrm{~m} / \mathrm{z}$ were observed. And the ion at $271 \mathrm{~m} / \mathrm{z}$ may have been produced by the losses of galloyl radicals (152 Da), 2 $\mathrm{HCHO}(30 \mathrm{Da})$ and $\mathrm{CO}_{2}$ (44 Da). Therefore, compound 7 was confirmed as 6'-O-galloyldesbenzoylpae oniflorin. Compounds 28 ( $\mathrm{tR}=39.0 \mathrm{~min}), 30$ ( $\mathrm{tR}=42.0 \mathrm{~min}$ ) and $39(\mathrm{tR}=48.2 \mathrm{~min})$ exhibited the $[\mathrm{M}-\mathrm{H}]^{-}$ion at $631 \mathrm{~m} / \mathrm{z}$. Considering the common fragmentation ions at 613,465 , 313 and $169 \mathrm{~m} / \mathrm{z}$, these three components were assigned as galloylpaeoniflorin $(14,15)$, galloylablbiflorin or their isomers; and this was consistent with the literature (10). Compounds $13(\mathrm{tR}=21.4 \mathrm{~min})$ and $15(\mathrm{tR}=24.3 \mathrm{~min})$ were two isomers with the solvent adduct ion $\left[\mathrm{M}-\mathrm{H}+\mathrm{CH}_{3} \mathrm{COOH}\right]^{-}$at $701 \mathrm{~m} / \mathrm{z}$. Compound $14(\mathrm{tR}=23.2 \mathrm{~min})$ produced $[\mathrm{M}-\mathrm{H}]^{-}$at $641 \mathrm{~m} / \mathrm{z}$. In addition, these compounds yielded a series of common ions, including [M-H-HCHO $]^{-}$at $611 \mathrm{~m} / \mathrm{z},\left[\mathrm{M}-\mathrm{H}-\mathrm{H}_{2} \mathrm{O}-\mathrm{HCHO}\right]^{-}$at $593 \mathrm{~m} / \mathrm{z}$, [M-H-BA] $^{-}$at $519 \mathrm{~m} / \mathrm{z}$ and [M-H-HCHO-BA] $]^{-}$at $489 \mathrm{~m} / \mathrm{z}$. By referring to the literature, compounds 13, 15 and
14 were identified as isomaltopaeoniflorin or isomers, and 6'-O-d-glucopyranosylalbiflorin (16).

Compounds 5 (tR=11.07 $\mathrm{min})$ and $6(\mathrm{tR}=11.64 \mathrm{~min})$ produced fragmentation ions at $313 \mathrm{~m} / \mathrm{z}$ [M-H-170]', $331 \mathrm{~m} / \mathrm{z}$ [M-H-152] $]^{-}$and $169 \mathrm{~m} / \mathrm{z}$ [gallic acid] ${ }^{-}$. Their fragment ions indicated the loss of the gallic acid moiety (170 Da) and/or galloyl radicals (152 Da) from the precursors of [M-H]; thus these two compounds were assigned as 1'-O-galloylsucrose, 6'-O-galloylsucrose. For compounds 19 (tR=33.9 min) and 20 (tR=34.5 min), fragmentation ions at $787 \mathrm{~m} / \mathrm{z}[\mathrm{M}-\mathrm{H}]^{-}, 617 \mathrm{~m} / \mathrm{z}$ [M-H-170]', $635 \mathrm{~m} / \mathrm{z}$ [M-H-152]', $483 \mathrm{~m} / \mathrm{z}$ [M-H-2galloyl] $]^{-}$and $465 \mathrm{~m} / \mathrm{z}$ [M-H-2galloyl- $\left.\mathrm{H}_{2} \mathrm{O}\right]^{-}$were produced in negative ion mode. Compounds 19 and 20 were tentatively identified as tetragalloylglucose or an isomer. Similarly, compound 29 was tentatively deduced as pentagalloylglucose, according to the fragmentation pathway and data in the literature (17). However, their structures were not elucidated from the MS data due to limited information regarding the linkage position of the galloyl groups relative to the glucose unit.

Compounds 8 (tR=15.8 $\mathrm{min}), 9$ ( $\mathrm{tR}=16.5 \mathrm{~min}), 34$ $(\mathrm{tR}=46.1 \mathrm{~min}), 35(\mathrm{tR}=46.6 \mathrm{~min})$ and $42(\mathrm{tR}=49.6 \mathrm{~min})$ were detected and matched with the data in the literature (10), revealing that they were identical to those of isomaltopaeoniflorin sulfonate, paeoniflorin sulfonate, benzoylpaeoniflorin sulfonate or their isomers.

Identification of the components of SYC derived from Radix Bupleuri. A total of six flavonoids, including baicalin, wogonoside, wogonin, apigenin-7-O- $\beta$-D-glucuronide and kaempferol or their isomers, were detected in the SYC extracts derived from Radix Bupleuri. Compounds 37 (tR=47.6 min) and $38(\mathrm{tR}=48.0 \mathrm{~min})$ provided common $[\mathrm{M}-\mathrm{H}]^{-}$ions at $445 \mathrm{~m} / \mathrm{z}$ and the MS/MS ion [M-H-gluconic acid] at $269 \mathrm{~m} / \mathrm{z}$. However, they exhibited different typical major ions at $251 \mathrm{~m} / \mathrm{z}$ ([M-H-gluconic acid- $\mathrm{H}_{2} \mathrm{O}^{-}$) and $175 \mathrm{~m} / \mathrm{z}$, respectively. Therefore, compound 38 was deduced as baicalin (16), and compound 37 was deduced as apigenin-7-O- $\beta$-D-glucuronide. Similarly, compounds $49(\mathrm{tR}=52.3 \mathrm{~min})$ and $50(\mathrm{tR}=54.4 \mathrm{~min})$ produced [M-H] $]^{-}$ions at $459 \mathrm{~m} / \mathrm{z}$, the $\mathrm{MS}^{2}$ ion at $283 \mathrm{~m} / \mathrm{z}$, corresponding to [M-H-gluconic acid] ${ }^{-}$, and the $\mathrm{MS}^{3}$ ion at $268 \mathrm{~m} / \mathrm{z}$, corresponding to [M-H-gluconic-acid- $\left.\mathrm{CH}_{3}\right]^{-}$. Accordingly, compounds 49,50 was tentatively identified as wogonoside or an isomer (16). Also, compound 67 ( $\mathrm{tR}=76.5 \mathrm{~min}$ ) was identified as wogonin, showing the $[\mathrm{M}-\mathrm{H}]^{-}$ion at $283 \mathrm{~m} / \mathrm{z}$ and the $\left[\mathrm{M}-\mathrm{H}-\mathrm{CH}_{3}\right]^{-}$ion at $268 \mathrm{~m} / \mathrm{z}$ (18). Another flavonoid had the characteristic fragment ion at $285 \mathrm{~m} / \mathrm{z}\left([\mathrm{M}-\mathrm{H}]^{-}\right)$and $269 \mathrm{~m} / \mathrm{z}\left([\mathrm{M}-\mathrm{H}-\mathrm{OH}]^{-}\right)$, therefore, compound 47 was identified as kaempferol.

A total of five saikosaponins (SSs) from the SYC extracts were identified or tentatively identified in the negative-ion ESI mode, among which two SSs, including SSa (compound 64; $\mathrm{tR}=71.9 \mathrm{~min}$ ) and $\mathrm{SSd}$ (compound 65; $\mathrm{tR}=72.4 \mathrm{~min}$ ) were identified through comparison of their $\mathrm{tR}$, and MSn data with those of the reference substances. Compound $60(\mathrm{tR}=65.4 \mathrm{~min})$ produced the $[\mathrm{M}-\mathrm{H}]^{-}$species at $811 \mathrm{~m} / \mathrm{z}$, and further produced the $[\mathrm{M}-\mathrm{H}-\mathrm{Glc}]^{-}$ion at $649 \mathrm{~m} / \mathrm{z}$ and the $\left[\mathrm{M}-\mathrm{H}-\mathrm{FucGlc}-\mathrm{CH}_{3} \mathrm{OH}\right]$ ion at $471 \mathrm{~m} / \mathrm{z}$, and was tentatively identified as $\mathrm{SS}_{3}$ or $\mathrm{SS}_{4}(16)$. Compound 68 (tR=77.3 $\mathrm{min}$ ) and compound 69 (tR=77.7 $\mathrm{min})$ shared the solvent adduct ion $\left[\mathrm{M}-\mathrm{H}+\mathrm{CH}_{3} \mathrm{COOH}\right]^{-}$at $677 \mathrm{~m} / \mathrm{z}$; and the common fragmentation ions were determined at 

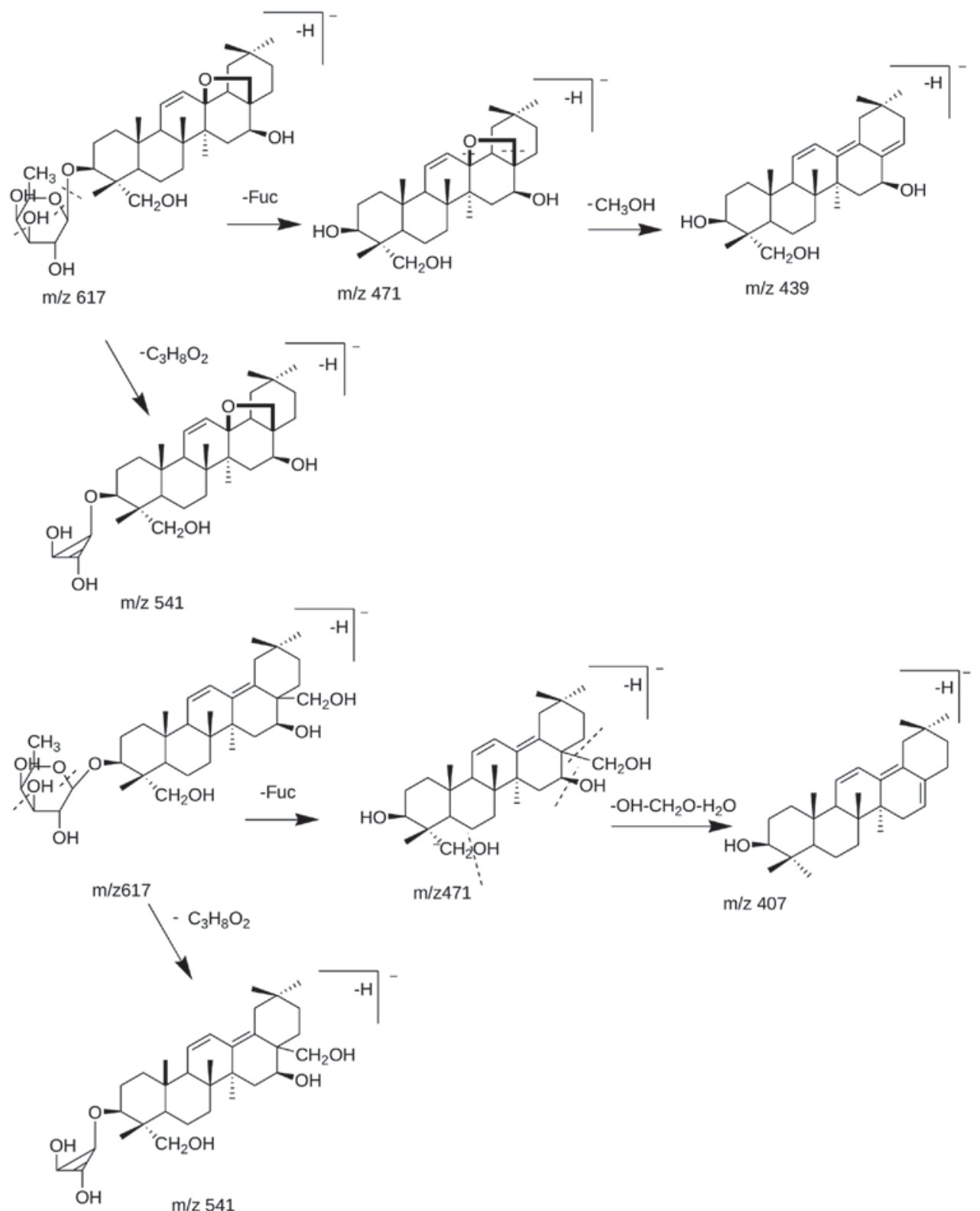

$\mathrm{m} / \mathrm{z} 407$

Figure 1. Suggested fragmentation pathways for compounds 68 and 69 .

$617 \mathrm{~m} / \mathrm{z}\left([\mathrm{M}-\mathrm{H}]^{-}\right), 541 \mathrm{~m} / \mathrm{z}$, corresponding to $\left[\mathrm{M}-\mathrm{H}-\mathrm{C}_{3} \mathrm{H}_{8} \mathrm{O}_{2}\right]$ and $471 \mathrm{~m} / \mathrm{z}$, corresponding to [M-H-Fuc] ${ }^{\text {. In addition, for }}$ compound $68,439 \mathrm{~m} / \mathrm{z}$ (corresponding to [M-H-Fuc- $\left.\mathrm{CH}_{3} \mathrm{OH}\right]^{-}$), was its additional fragmentation ion; and for compound 69, $407 \mathrm{~m} / \mathrm{z}$ ([M-H-Fuc-OH- $\left.\left.\mathrm{CH}_{2} \mathrm{O}-\mathrm{H}_{2} \mathrm{O}\right]^{-}\right)$was its additional fragmentation ion. According to the common and additional fragmentation ions, compound 68 was tentatively deduced as prosaikogenin $\mathrm{G}$ or prosaikogenin $\mathrm{F}$, and compound 69 was identified as prosaikogenin A or prosaikogenin D (19). The structure of compound 68/69 and the possible fragmentation patterns are summarized in Fig. 1. In addition, compounds 68 and 69 were possible secondary metabolites of the SSs in the plants during processing, storage or long-distance transport (20).

Identification of the components of SYC from Radix Glycyrrhizae. A total of 28 compounds, including flavanones, isoflavanones, coumarins and saponins were detected in the
SYC extracts derived from Radix Glycyrrhizae. Compounds 24 $(\mathrm{tR}=35.3 \mathrm{~min}), 26(\mathrm{tR}=35.9 \mathrm{~min}), 40(\mathrm{tR}=48.5 \mathrm{~min}), 41$ $(\mathrm{tR}=48.9 \mathrm{~min})$ and $43(\mathrm{tR}=49.5 \mathrm{~min})$ exhibited the same $[\mathrm{M}-\mathrm{H}]^{-}$ ion at $417 \mathrm{~m} / \mathrm{z}$. The fragment ion at $255 \mathrm{~m} / \mathrm{z}$ was observed by loss of a glucose residue (162 Da). The alycone ion at $255 \mathrm{~m} / \mathrm{z}$ was then further fragmented to the product ion at 153, 135 or $119 \mathrm{~m} / \mathrm{z}$ through Retro-Diels-Alder (RDA) cleavage. Thus, compounds 24, 26, 40, 41 and 43 were tentatively identified as neoliquiritin, liquiritin, isoliquiritin, neoisoliquiritin and neoisoliquiritin isomer (21).

The two isomeric compounds 23 ( $\mathrm{tR}=35.2 \mathrm{~min}$ ) and 36 ( $\mathrm{tR}=47.1 \mathrm{~min}$ ) exhibited identical MS data in the negative ion mode. With the exception of the same $[\mathrm{M}-\mathrm{H}]^{-}$ion at $549 \mathrm{~m} / \mathrm{z}$, their MS/MS spectra exhibited [M-H-xyl] ${ }^{-}$at $417 \mathrm{~m} / \mathrm{z}$ [M-H-xyl-glc] ${ }^{-}$at $255 \mathrm{~m} / \mathrm{z}$, and the product ion at 135 or $119 \mathrm{~m} / \mathrm{z}$. Thus, compound 23 was deduced as liquiritin apioside and compound 36 was tentatively identified as isoliquiritin apioside. Compound $25(\mathrm{tR}=35.7 \mathrm{~min})$ shared 

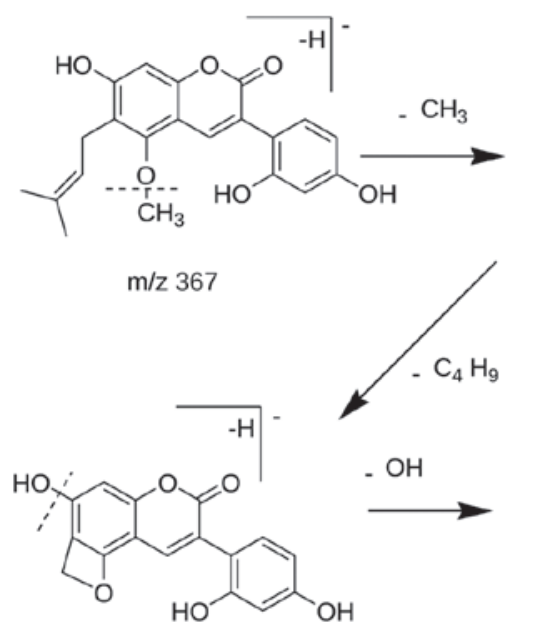

$\mathrm{m} / \mathrm{z} 297$

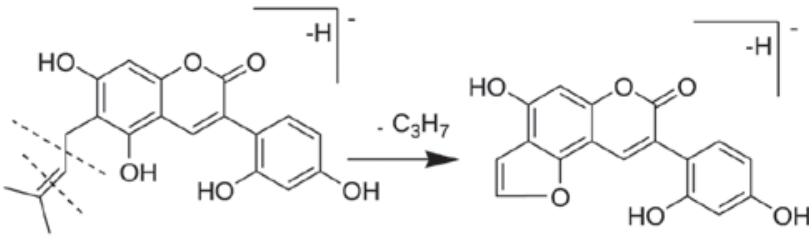

$\mathrm{m} / \mathrm{z} 352$

$\mathrm{m} / \mathrm{z} 309$

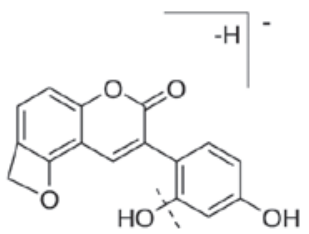

$\mathrm{m} / \mathrm{z} 281$

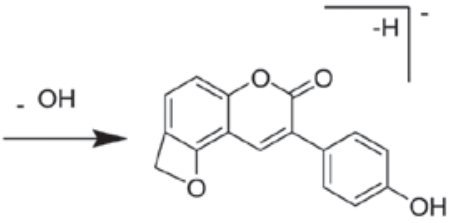

$\mathrm{m} / \mathrm{z} 265$

Figure 2. Suggested fragmentation pathway for compounds 66 and 70.

a series of characteristic ions at 417, 255 and $135 \mathrm{~m} / \mathrm{z}$ with liquiritin, and its molecular weight was $36 \mathrm{D}$ higher than that of liquiritin, indicating that compound 25 was hydrated liquiritin.

The three isomeric compounds $44(\mathrm{tR}=49.7 \mathrm{~min}), 48$ $(\mathrm{tR}=52.1 \mathrm{~min})$ and $59(\mathrm{tR}=65.1 \mathrm{~min})$ produced the same ion $[\mathrm{M}-\mathrm{H}]^{-}$at $255 \mathrm{~m} / \mathrm{z}$, which was further fragmented to the product ion at 135,153 or $119 \mathrm{~m} / \mathrm{z}$ via the RDA reaction (22). Thus, compounds 44, 48 and 59 were identified as liquiritigenin, liquiritigenin isomer and isoliquiritigenin. Compounds 45 $(\mathrm{tR}=50.0 \mathrm{~min})$ and $46(\mathrm{tR}=50.2 \mathrm{~min})$ showed $[\mathrm{M}-\mathrm{H}]^{-}$ions at 695 and $725 \mathrm{~m} / \mathrm{z}$. The two compounds exhibited the common product ion at 549,531 and $255 \mathrm{~m} / \mathrm{z}$. In the MS/MS spectrum, compounds 45 and 46 produced [M-H-rhamnosyl] $]^{-}$and [M-H-176] at $549 \mathrm{~m} / \mathrm{z}$, respectively. They subsequently produced the $\mathrm{MS}^{3}$ ion at $255 \mathrm{~m} / \mathrm{z}$ by losing a glucose residue (162 Da) and an apiose residue (132 Da). Therefore, compounds 45 and 46 were identified as licorice-glycoside B and licorice-glycoside A (22).

Compound $22(\mathrm{tR}=34.70 \mathrm{~min})$ exhibited $[\mathrm{M}-\mathrm{H}]^{-}$at $577 \mathrm{~m} / \mathrm{z}$. In the MS/MS spectrum, the [M-H-120] ion at $457 \mathrm{~m} / \mathrm{z}$, the [M-H-74] $]^{-}$ion at $503 \mathrm{~m} / \mathrm{z}$ and the [M-H-120-74] $]^{-}$ion at $383 \mathrm{~m} / \mathrm{z}$ suggested flavone C-glucosides, and these produced typical losses of $120 \mathrm{Da}$ from the precursor ions; and the flavone C-rhamnosides generated the product ions by losing $74 \mathrm{Da}$. Compound 22 was deduced to be isoviolanthin (22). Compound 63 (tR=66.8 min) was identified as formononetin, according to the $[\mathrm{M}-\mathrm{H}]^{-}$ion at $267 \mathrm{~m} / \mathrm{z}$ and the $\left[\mathrm{M}-\mathrm{H}-\mathrm{CH}_{3}\right]^{-}$ion at $252 \mathrm{~m} / \mathrm{z}$.

The two isomeric compounds $71(\mathrm{tR}=82.0 \mathrm{~min})$ and 72 ( $\mathrm{tR}=83.0 \mathrm{~min}$ ) exhibited the $[\mathrm{M}-\mathrm{H}]^{-}$ion at $353 \mathrm{~m} / \mathrm{z}$, corresponding to the product ion at $297 \mathrm{~m} / \mathrm{z}$; therefore, they were identified as licoisoflavone A or an isomer, according to the literature (23). In addition, compound 73 (tR=83.3 $\mathrm{min}$ ) exhibited the $[\mathrm{M}-\mathrm{H}]^{-}$ion at $381 \mathrm{~m} / \mathrm{z}$, corresponding to the product ion at $366 \mathrm{~m} / \mathrm{z}$ in the MS/MS spectra. Thus, compound 73 was deduced as licoricone.

Compounds $57(\mathrm{tR}=61.5 \mathrm{~min})$ and $58(\mathrm{tR}=62.1 \mathrm{~min})$ exhibited the deprotonated molecule $[\mathrm{M}-\mathrm{H}]^{-}$ion at 837 and
$819 \mathrm{~m} / \mathrm{z}$, respectively. The [M-H] $]^{-}$ion of the two compounds fragmented into two products at $351 \mathrm{~m} / \mathrm{z}$ ([glucuroglucuronic acid-H $]^{-}$) and $193 \mathrm{~m} / \mathrm{z}$ ([glucuronic acid-H]'). Furthermore the $[\mathrm{M}-\mathrm{H}-\mathrm{gluA}]^{-}$ion and the $\left[\mathrm{M}-\mathrm{H}-\mathrm{H}_{2} \mathrm{O}\right]^{-}$ion were also detected in the MS/MS spectra of the two compounds. Based upon the above fragmentation pattern and previous literature (22), compounds 57 and 58 were identified as licorice-saponin $\mathrm{G} 2$ and licorice-saponin E2. Compounds 61 (tR=65.5 $\mathrm{min}$ ) and $62(\mathrm{tR}=66.3 \mathrm{~min})$ generated $[\mathrm{M}-\mathrm{H}]^{-}$at $821 \mathrm{~m} / \mathrm{z}$ in the negative ion mode. The $[\mathrm{M}-\mathrm{H}]^{-}$ion fragmented into two characteristic ions at 645 and $469 \mathrm{~m} / \mathrm{z}$, which corresponded to [M-H-glucuronic acid] ${ }^{-}$and [M-H-di-glucuronic acid]', respectively. Therefore, compounds 61 and 62 were identified as glycyrrhizin and uralsaponin A, according to the literature (22).

Only two coumarins were present in SYC, and these were identified as glycycoumarin. Compounds $66(\mathrm{tR}=72.7 \mathrm{~min})$ and $70\left(\mathrm{tR}=80.4 \mathrm{~min}\right.$ ) exhibited the $[\mathrm{M}-\mathrm{H}]^{-}$ion at $367 \mathrm{~m} / \mathrm{z}$, and the $\mathrm{MS} / \mathrm{MS}$ spectrum produced the $\left[\mathrm{M}-\mathrm{H}-\mathrm{CH}_{3}\right]^{-}$ion at $352 \mathrm{~m} / \mathrm{z}$, $\left[\mathrm{M}-\mathrm{H}-\mathrm{CH}_{3}-\mathrm{C}_{3} \mathrm{H}_{7}\right]^{-}$ion at $309 \mathrm{~m} / \mathrm{z}$ and $\left[\mathrm{M}-\mathrm{H}-\mathrm{CH}_{3}-\mathrm{C}_{4} \mathrm{H}_{9}\right]^{-}$ion at $297 \mathrm{~m} / \mathrm{z}$. The $\mathrm{C}_{3} \mathrm{H}_{7}$ and $\mathrm{C}_{4} \mathrm{H}_{9}$ fragment ions corresponded to an isopentenyl residue. The further loss of an oxhydryl group generated an ion at $281 \mathrm{~m} / \mathrm{z}$. Compounds 66 and 70 were then identified as glycycoumarin (24). The fragmentation pathway of glycycoumarin is shown in Fig. 2 .

Compound $56(\mathrm{tR}=59.2 \mathrm{~min})$ exhibited the $[\mathrm{M}-\mathrm{H}]^{-}$ion at $271 \mathrm{~m} / \mathrm{z}$, and produced two major product ions at $151 \mathrm{~m} / \mathrm{z}$ $\left(\left[\mathrm{C}_{7} \mathrm{H}_{3} \mathrm{O}_{4}\right]^{-}\right)$and $119 \mathrm{~m} / \mathrm{z}\left(\left[\mathrm{C}_{8} \mathrm{H}_{7} \mathrm{O}\right]^{-}\right)$, in agreement with the classic 1,3A- and 1,3B-fragments. This indicated the presence of two and one hydroxyl groups substituted on rings $\mathrm{A}$ and $\mathrm{B}$ of a flavanone, respectively, further confirming the identity of compound 56 as naringenin, a known compound in Glycyrrhizae Radix et Rhizoma (25). Compound 31 $(\mathrm{tR}=44.0 \mathrm{~min})$ exhibited the deprotonated molecule $[\mathrm{M}-\mathrm{H}]^{-}$at $433 \mathrm{~m} / \mathrm{z}$ and produced predominant fragment ions at $271 \mathrm{~m} / \mathrm{z}$ [M-H-glc] in the $\mathrm{MS}^{2}$ spectra and $\mathrm{MS}^{3}$ ions at 151 and $119 \mathrm{~m} / \mathrm{z}$, which was in accordance with the fragmentation pattern of naringenin. Therefore, compound 31 was deduced as naringenin-O-glucose (26). 
Table II. MS and MS ${ }^{\mathrm{n}}$ data of the identified metabolites absorbed in rat serum following oral administration of SYC in negative mode.

\begin{tabular}{|c|c|c|c|c|c|c|}
\hline No. & $\mathrm{t}_{\mathrm{R}}^{\mathrm{a}}$ & Formula & $\begin{array}{c}{[\mathrm{M}-\mathrm{H}]^{-}} \\
(\mathrm{m} / \mathrm{z})\end{array}$ & $\operatorname{MS}^{\mathrm{n}}(\mathrm{m} / \mathrm{z})$ & $\begin{array}{l}\text { Possible } \\
\text { original compound }\end{array}$ & Identification \\
\hline $\mathrm{M} 1^{\mathrm{n}}$ & 5.6 & $\mathrm{C}_{22} \mathrm{H}_{26} \mathrm{O}_{11}$ & 465 & $345,165,327$ & Paeoniflorin & $\begin{array}{l}\text { Dehydroxylate Demethylene } \\
\text { oxypaeoniflorin }\end{array}$ \\
\hline M2 & 7.2 & $\mathrm{C}_{9} \mathrm{H}_{10} \mathrm{O}_{7} \mathrm{~S}$ & 261 & 215,171 & Catechin-associated & $\begin{array}{l}3,4 \text {-Dihydroxy phenylpropionic } \\
\text { acid sulfate }\end{array}$ \\
\hline $\mathrm{M}^{\mathrm{n}}$ & 14.0 & $\mathrm{C}_{22} \mathrm{H}_{30} \mathrm{O}_{16}$ & 549 & $373,197,175$ & Paeoniflorin & PaeonimetabolinIdi-glucuronide \\
\hline M4 & 14.1 & $\mathrm{C}_{8} \mathrm{H}_{8} \mathrm{O}_{8} \mathrm{~S}$ & 263 & 183,167 & Gallic acid-associated & $\begin{array}{l}\text { 4-O-Methyl gallic acid sulfate or } \\
\text { 3-O- Methyl gallic acid sulfate }\end{array}$ \\
\hline M5 & 16.5 & $\mathrm{C}_{23} \mathrm{H}_{28} \mathrm{O}_{13} \mathrm{~S}$ & 543 & $421,375,259,497$ & Paeoniflorin & Paeoniflorin sulfonate \\
\hline M6 & 18.1 & $\mathrm{C}_{7} \mathrm{H}_{6} \mathrm{O}_{7} \mathrm{~S}$ & 233 & 189 & Gallic acid-associated & Protocatechuic acid-4-O-sulfate \\
\hline M7 & 19.8 & $\mathrm{C}_{27} \mathrm{H}_{30} \mathrm{O}_{15}$ & 593 & 417,255 & Flavonoid-associated & liquiritin glucuronide \\
\hline $\mathrm{M}^{\mathrm{n}}$ & 20.3 & $\mathrm{C}_{22} \mathrm{H}_{30} \mathrm{O}_{16}$ & 549 & $373,197,175$ & Paeoniflorin & PaeonimetabolinIdi-glucuronide \\
\hline M9 & 22.0 & $\mathrm{C}_{15} \mathrm{H}_{18} \mathrm{O}_{11}$ & 373 & 197,175 & Paeoniflorin & PaeonimetabolinIglucuronide \\
\hline M10 & 24.0 & $\mathrm{C}_{9} \mathrm{H}_{8} \mathrm{O}_{6} \mathrm{~S}$ & 243 & 163 & Catechin-associated & m-Coumaric acid sulfate \\
\hline M11 & 24.5 & $\mathrm{C}_{7} \mathrm{H}_{6} \mathrm{O}_{7} \mathrm{~S}$ & 233 & 189 & Gallic acid-associated & Protocatechuic acid-3-O-sulfate \\
\hline $\mathrm{M} 12^{\mathrm{n}}$ & 26.8 & $\mathrm{C}_{17} \mathrm{H}_{24} \mathrm{O}_{10}$ & 387 & $211,197,175$ & Gallic acid-associated & Trimethyl gallic acid glucuronide \\
\hline $\mathrm{M}^{1} 3^{\mathrm{n}}$ & 27.8 & $\mathrm{C}_{22} \mathrm{H}_{20} \mathrm{O}_{11}$ & 459 & 283,267 & Flavonoid-associated & $\begin{array}{l}\text { Formononetin hydroxylate } \\
\text { glucuronide or isomer }\end{array}$ \\
\hline $\mathrm{M} 14^{\mathrm{n}}$ & 29.1 & $\mathrm{C}_{22} \mathrm{H}_{26} \mathrm{O}_{10}$ & $569 \Delta$ & $449,327,539,509$ & Paeoniflorin & methyl hydroxylate paeoniflorin \\
\hline $\mathrm{M} 15^{\mathrm{n}}$ & 32.1 & $\mathrm{C}_{21} \mathrm{H}_{28} \mathrm{O}_{13}$ & 487 & 311,267 & Flavonoid-associated & $\begin{array}{l}\text { Di-methyl-formononetin } \\
\text { hydroxylate glucuronide }\end{array}$ \\
\hline M16 & 34.3 & $\mathrm{C}_{26} \mathrm{H}_{26} \mathrm{O}_{12}$ & 529 & 353,175 & Flavonoid-associated & Licoisoflavone A glucuronide \\
\hline M17 & 34.7 & $\mathrm{C}_{21} \mathrm{H}_{20} \mathrm{O}_{10}$ & 431 & $255,175,135,119$ & Flavonoid-associated & Liquiritigenin-4,-O-glucuronide \\
\hline M18 & 35.3 & $\mathrm{C}_{21} \mathrm{H}_{20} \mathrm{O}_{10}$ & 431 & $255,175,135$ & Flavonoid-associated & Liquiritigenin-7-O-glucuronide \\
\hline M19 & 35.7 & $\mathrm{C}_{10} \mathrm{H}_{12} \mathrm{O}_{8} \mathrm{~S}$ & 291 & 211,197 & Gallic acid-associated & Di-methyl $\mathrm{C}_{8} \mathrm{H}_{8} \mathrm{O}_{8} \mathrm{~S}$ \\
\hline M20 & 36.1 & $\mathrm{C}_{21} \mathrm{H}_{20} \mathrm{O}_{10}$ & 431 & $255,175,135$ & Flavonoid-associated & Isoliquiritigenin-4. $\mathrm{O}$-glucuronide \\
\hline M21 & 36.7 & $\mathrm{C}_{21} \mathrm{H}_{20} \mathrm{O}_{10}$ & 431 & 255,175 & Flavonoid-associated & Isoliquiritigenin-7-O-glucuronide \\
\hline M22 & 37.3 & $\mathrm{C}_{21} \mathrm{H}_{20} \mathrm{O}_{11}$ & 447 & 271,151 & Flavonoid-associated & Naringenin glucuronide \\
\hline M23 & 39.9 & $\mathrm{C}_{7} \mathrm{H}_{6} \mathrm{O}_{7} \mathrm{~S}$ & 233 & 189 & Gallic acid-associated & Protocatechuic acid-3-O-sulfate \\
\hline M24 & 41.6 & $\mathrm{C}_{27} \mathrm{H}_{32} \mathrm{O}_{14}$ & 579 & 271,151 & Flavonoid-associated & Naringenin-O-rutinoside \\
\hline M25 & 42.4 & $\mathrm{C}_{13} \mathrm{H}_{14} \mathrm{O}_{8}$ & 297 & 175,113 & Gallic acid-associated & Benzoyl glucuronide \\
\hline M26 & 42.8 & $\mathrm{C}_{14} \mathrm{H}_{16} \mathrm{O}_{14} \mathrm{~S}$ & 439 & 263,121 & Gallic acid-associated & $\mathrm{C}_{8} \mathrm{H}_{8} \mathrm{O}_{8} \mathrm{~S}$ glucuronide \\
\hline M27 & 43.1 & $\mathrm{C}_{26} \mathrm{H}_{26} \mathrm{O}_{12}$ & 529 & 353,175 & Flavonoid-associated & Na Licoisoflavone A glucuronide \\
\hline M28 & 43.3 & $\mathrm{C}_{9} \mathrm{H}_{10} \mathrm{O}_{8} \mathrm{~S}$ & 277 & 197,169 & Gallic acid-associated & $\begin{array}{l}\text { 3,4-Di-O-methyl gallic acid } \\
\text { sulfate }\end{array}$ \\
\hline M29 & 43.9 & $\mathrm{C}_{21} \mathrm{H}_{20} \mathrm{O}_{11}$ & 447 & 271,151 & Flavonoid-associated & Naringenin glucuronide \\
\hline M30 & 44.5 & $\mathrm{C}_{27} \mathrm{H}_{30} \mathrm{O}_{16}$ & 609 & $301,286,242$ & Flavonoid-associated & Hesperidin \\
\hline M31 & 45.7 & $\mathrm{C}_{15} \mathrm{H}_{12} \mathrm{O}_{7} \mathrm{~S}$ & 335 & $255,135,119$ & Flavonoid-associated & Liquiritigenin-4, -O-sulfate \\
\hline M32 & 45.9 & $\mathrm{C}_{15} \mathrm{H}_{12} \mathrm{O}_{7} \mathrm{~S}$ & 335 & $255,135,119$ & Flavonoid-associated & Liquiritigenin-7-O-sulfate \\
\hline M33 & 46.7 & $\mathrm{C}_{17} \mathrm{H}_{22} \mathrm{O}_{11}$ & 401 & 225 & Uncertain & Methyl propyl gallate glucuronide \\
\hline $\mathrm{M} 34^{\mathrm{n}}$ & 49.0 & $\mathrm{C}_{23} \mathrm{H}_{22} \mathrm{O}_{11}$ & 473 & 297,253 & Flavonoid-associated & $\begin{array}{l}\text { Methyl formononetin } \\
\text { hydroxylate glucuronide }\end{array}$ \\
\hline M35 & 50.3 & $\mathrm{C}_{21} \mathrm{H}_{20} \mathrm{O}_{10}$ & 431 & $255,135,119,175$ & Flavonoid-associated & $\begin{array}{l}\text { Isoliquiritigenin glucuronide } \\
\text { isomer }\end{array}$ \\
\hline $\mathrm{M} 36^{\mathrm{n}}$ & 50.4 & $\mathrm{C}_{15} \mathrm{H}_{18} \mathrm{O}_{11}$ & 453 & 277,233 & Gallic acid-associated & $\mathrm{C}_{9} \mathrm{H}_{10} \mathrm{O}_{5}$ glucuronide \\
\hline M37 & 51.1 & $\mathrm{C}_{17} \mathrm{H}_{12} \mathrm{O}_{8}$ & 343 & $229,165,149$ & Ellagic acid & 3,7,8-Trimethyl ellagic acid \\
\hline M38 & 51.3 & $\mathrm{C}_{21} \mathrm{H}_{22} \mathrm{O}_{13}$ & 433 & 257,175 & Flavonoid-associated & Davidigenin glucuronide \\
\hline M39 & 51.5 & $\mathrm{C}_{17} \mathrm{H}_{12} \mathrm{O}_{8}$ & 343 & $229,149,165$ & Ellagic acid & 3,7,8-Trimethyl ellagic acid \\
\hline $\mathrm{M} 40^{\mathrm{n}}$ & 52.1 & $\mathrm{C}_{30} \mathrm{H}_{48} \mathrm{O}_{3}$ & 455 & 437 & Saponin-associated & Saikogenin B \\
\hline M41 & 54.8 & $\mathrm{C}_{22} \mathrm{H}_{24} \mathrm{O}_{15} \mathrm{~S}$ & 559 & $515,383,339$ & Coumarin-associated & $\begin{array}{l}\text { Glycycoumarin hydroxylate } \\
\text { glucuronide }\end{array}$ \\
\hline $\mathrm{M} 42^{\mathrm{n}}$ & 54.9 & $\mathrm{C}_{22} \mathrm{H}_{20} \mathrm{O}_{11}$ & 459 & 283,267 & Flavonoid-associated & $\begin{array}{l}\text { Formononetin hydroxylate } \\
\text { glucuronide or isomer }\end{array}$ \\
\hline
\end{tabular}


Table II. Continued.

\begin{tabular}{|c|c|c|c|c|c|c|}
\hline No. & $t_{R}{ }^{a}$ & Formula & $\begin{array}{c}{[\mathrm{M}-\mathrm{H}]^{-}} \\
(\mathrm{m} / \mathrm{z})\end{array}$ & $\mathrm{MS}^{\mathrm{n}}(\mathrm{m} / \mathrm{z})$ & $\begin{array}{c}\text { Possible } \\
\text { original compound }\end{array}$ & Identification \\
\hline M43 & 56.6 & $\mathrm{C}_{16} \mathrm{H}_{12} \mathrm{O}_{7} \mathrm{~S}$ & 347 & 267,252 & Flavonoid-associated & Formononetin sulfate \\
\hline M44 & 57.0 & $\mathrm{C}_{16} \mathrm{H}_{12} \mathrm{O}_{7} \mathrm{~S}$ & 347 & 267,252 & Flavonoid-associated & Formononetin sulfate \\
\hline $\mathrm{M} 45^{\mathrm{n}}$ & 58.3 & $\mathrm{C}_{26} \mathrm{H}_{28} \mathrm{O}_{11}$ & 515 & 353 & Flavonoid-associated & Licoisoflavone A glucose \\
\hline M46 & 61.3 & $\mathrm{C}_{15} \mathrm{H}_{22} \mathrm{O}_{9}$ & $405^{\mathrm{b}}$ & 345,327 & Paeoniflorin & $\begin{array}{l}\text { Dehydroxylate Demethylene } \\
\text { desbenzoylpaeoniflorin }\end{array}$ \\
\hline $\mathrm{M} 47^{\mathrm{n}}$ & 61.4 & $\mathrm{C}_{15} \mathrm{H}_{22} \mathrm{O}_{9}$ & $405^{\mathrm{b}}$ & 345,327 & Paeoniflorin & $\begin{array}{l}\text { Dehydroxylate Demethylene } \\
\text { desbenzoylpaeoniflorin }\end{array}$ \\
\hline M48 & 67.0 & $\mathrm{C}_{16} \mathrm{H}_{14} \mathrm{O}_{9}$ & 349 & 303,287 & Flavonoid-associated & $\begin{array}{l}\text { Dihydroxyl methyl quercetin } \\
\text {-chalcone }\end{array}$ \\
\hline M49 & 71.6 & $\mathrm{C}_{21} \mathrm{H}_{20} \mathrm{O}_{9} \mathrm{~S}$ & 447 & 367 & Coumarin-associated & Glycycoumarin sulfate \\
\hline
\end{tabular}

${ }^{a} t_{R}$, retention time; ${ }^{b}$ solvent adduct ion $\left[\mathrm{M}-\mathrm{H}+\mathrm{CH}_{3} \mathrm{COOH}\right]-; \mathrm{n}$, novel metabolites of certain constituents of SYC; SYC, Shu-Yu capsule; MS, mass spectrometry.

Identification of the absorbed components in rat serum following oral administration of SYC extracts. The absorbed components and metabolites were difficult to elucidate due to their low concentrations. In order to improve the detection sensitivity, extracted ion chromatograms (EICs) were used. First, the protonated molecular ions in Table I were used one by one to obtain EICs from the dosed rat serum, blank rat serum and SYC extract simultaneously. Subsequently, by comparing these obtained EICs, components that appeared in the dosed rat serum and SYC extract, but not in the blank rat serum, were considered to be the components absorbed into serum in the prototype. Once these components were determined as the absorbed components, they were further confirmed by carefully comparing their $\mathrm{MS}, \mathrm{MS}^{\mathrm{n}}$ data and retention times with those in Table I. As a result, 13 prototype compounds were absorbed into the rat serum in the prototype and identified as quinic acid, desbenzoylpaeoniflorin, 6'-O-galloyldesbenzoylpaeoniflorin paeoniflorin sulfonate, albiflorin, paeoniflorin, liquiritin apioside, liquiritin, hydrated-liquiritin, galloylpaeoniflorin, galloylalbiflorin, apigenin-7-O- $\beta$-D-glucuronide and wogonoside.

Identification of the metabolites from rat serum following oral administration of SYC. Drug metabolism involves two types of enzyme-catalyzed reactions, phase I and phase II. Phase I metabolism includes oxidation, reduction, hydroxylation and desaturation; phase II metabolism includes glucuronidation, sulfation and glutathione conjugation, which may occur directly on the parent compounds, which contain appropriate structural motifs, or, as is usually the case, on functional groups added or exposed by phase I oxidation. These results increase the solubility of the drug metabolites in water, causing them to be more easily excreted from the body (27). In the present study, sulfation, glucuronidation and methylation were detected as the predominant phase II reactions, and the oxidation reaction and demethylation were observed as the predominant phase I reactions. In general, 49 compounds were considered as metabolites of SYC (Table II), in which 14 metabolites were confirmed as novel compounds.
Identification of gallic acid-associated metabolites. In the present study, a total of 10 compounds were identified as metabolites of gallic acid or polyphenols, which can be degraded into gallic acid in the body. The possible metabolic pathways of gallic acid and the associated compounds are presented in Fig. 3.

M4 exhibited the $[\mathrm{M}-\mathrm{H}]^{-}$ion at $263 \mathrm{~m} / \mathrm{z}$, which yielded the $\mathrm{MS} / \mathrm{MS}$ ion at $183 \mathrm{~m} / \mathrm{z}$ with a loss of $80 \mathrm{Da}\left(\mathrm{SO}_{3}\right)$, and the $\mathrm{MS}^{3}$ ion at $167 \mathrm{~m} / \mathrm{z}$, suggesting that gallic acid underwent the sulfation and methylation reactions. Therefore, M4 was tentatively identified as 4-O-methyl gallic acid sulfate or 3-O-methyl gallic acid sulfate. M26 exhibited the $[\mathrm{M}-\mathrm{H}]^{-}$ion at $439 \mathrm{~m} / \mathrm{z}$ and yielded the product ions at $263 \mathrm{~m} / \mathrm{z}$, corresponding to a loss of $176 \mathrm{Da}$. Thus, M26 was tentatively identified as $\mathrm{C}_{8} \mathrm{H}_{8} \mathrm{O}_{8} \mathrm{~S}$ glucuronide. $\mathrm{M} 28$ showed an [M-H] ion at $277 \mathrm{~m} / \mathrm{z}$, the product ion at $197 \mathrm{~m} / \mathrm{z}$ and the $\mathrm{MS}^{3}$ ion at $169 \mathrm{~m} / \mathrm{z}$ with a loss of $28 \mathrm{Da}$ via the $\mathrm{MS}^{2}$ spectrum, suggesting that M28 was a sulfate conjugate of dimethyl gallic acid. In addition, M19 exhibited the $[\mathrm{M}-\mathrm{H}]^{-}$ion at $291 \mathrm{~m} / \mathrm{z}$, which is $28 \mathrm{Da}$ higher than M4, and the product ion at $211 \mathrm{~m} / \mathrm{z}$ with a loss of $80 \mathrm{Da}$ $\left(\mathrm{SO}_{3}\right)$, suggesting that they were sulfate conjugates, indicating that M19 was the dimethyl conjugate of M4. M36 exhibited the $[\mathrm{M}-\mathrm{H}]^{-}$ion at $453 \mathrm{~m} / \mathrm{z}$ and the product ion at $277 \mathrm{~m} / \mathrm{z}$ with a loss of 176 Da, indicating that M36 was the glucuronide conjugate of M28.

M6 and M11 exhibited an [M-H] ion at $233 \mathrm{~m} / \mathrm{z}$, which produced product ions at 189 and $153 \mathrm{~m} / \mathrm{z}$, suggesting that they were sulfate conjugates. Thus, M6 was determined as protocatechuic acid-4-sulfate, whereas M11 was identified as protocatechuic acid-3-sulfate, with reference to previous reports (15). M12 exhibited the $[\mathrm{M}-\mathrm{H}]^{-}$ion at $387 \mathrm{~m} / \mathrm{z}$ and yielded product ions at 211,197 and $175 \mathrm{~m} / \mathrm{z}$, indicating that M12 was a glucuronide conjugate of the three methylation products of gallic acid. M25 exhibited the [M-H] $]^{-}$ion at $297 \mathrm{~m} / \mathrm{z}$ and the product ion at $121 \mathrm{~m} / \mathrm{z}$ with a loss of $176 \mathrm{Da}$, indicating that M25 was the glucuronide conjugate of benzoic acid.

Identification of paeoniflorin-associated metabolites. In the present study, a total of eight compounds detected in 
the rat serum were tentatively assigned as metabolites originating from paeoniflorin, which may also be the metabolites of other paeoniflorin-associated compounds, including desbenzoylpaeoniflorin or oxypaeoniflorin. With the exception of M5 (paeoniflorin sulfonate) and M9 (paeonimetabolinIglucuronide), the other six metabolites were identified for the first time as metabolites of paeoniflorin. The suggested metabolic pathways for paeoniflorin are shown in Fig. 4.

M9 exhibited the $\mathrm{MS}^{2}$ spectra [aglycon-H] and [glucuronyl-H] $]^{-}$at 197 and $175 \mathrm{~m} / \mathrm{z}$, and we tentatively assigned as paeonimetabolin I glucuronides. M3 and M8 shared with M9 a series of characteristic ions at 175, 197 and $373 \mathrm{~m} / \mathrm{z}$. In addition, M3 and M8 were 176 Da higher than M9. Thus, M3 and M8 were assigned as glucuronide conjugates of M9.

Paeoniflorin sulfate absorbed M5 into the serum, and may be the metabolite of paeoniflorin through sulfation in vivo. A proportion of the paeoniflorin sulfate was most likely absorbed into the rat serum in the prototype from the SYC extract.

M14 exhibited the solvent adduct ion $\left[\mathrm{M}-\mathrm{H}+\mathrm{CH}_{3} \mathrm{COOH}\right]$ at $569 \mathrm{~m} / \mathrm{z}$ and shared the same characteristic ions at 165, 327, 449 and $479 \mathrm{~m} / \mathrm{z}$ with paeoniflorin. In addition, compared with the molecular weight of paeoniflorin, these other species were 30 Da higher via methylation and hydroxylation reactions. Thus M14 was tentatively identified as methyl hydroxylate paeoniflorin. M1, M46 and M47 shared the same MS/MS fragmentation ion at $345 \mathrm{~m} / \mathrm{z}$ and a further fragmentation ion at $327 \mathrm{~m} / \mathrm{z}$ with a loss of $18 \mathrm{Da}$. In addition, M46 and M47 exhibited the solvent adduct ion $\left[\mathrm{M}-\mathrm{H}+\mathrm{CH}_{3} \mathrm{COOH}\right]^{-}$at $405 \mathrm{~m} / \mathrm{z}$, and M1 exhibited the deprotonated ion $[\mathrm{M}-\mathrm{H}]^{-}$at $465 \mathrm{~m} / \mathrm{z}$. Based on the information presented above, M1 was tentatively identified as dehydroxylate demethylene oxypaeoniflorin. M46/M47 was tentatively identified as dehydroxylate demethylene desbenzoylpaeoniflorin or its isomer.

Identification of flavonoid-associated metabolites. A total of 19 compounds were identified as metabolites originating from dihydroflavone, flavanones and isoflavonoids, including liquiritin, kaempferol, licoisoflavone A and formononetin. Their LC-MS ${ }^{\mathrm{n}}$ data are summarized in Table II, and the possible metabolic pathways of liguiritin are presented in Figs. 5 and 6.

Liquiritin was first metabolized into its aglycone liquiritigenin, and liquititigenin was then conjugated with glucuronide and sulfate. Isomerization into chalcones was also common for liquiritin. The present study revealed that M7, M17, M18, M31 and M32 were detected as major metabolites of liquiritin; and M20, M21, M38 and M35 were assigned as major metabolites of isoliquiritin. M17, M18, M20, M21 and M35 exhibited identical protonated molecules at $431 \mathrm{~m} / \mathrm{z}$, which produced identical product ions at 255, 135 and $119 \mathrm{~m} / \mathrm{z}$ with a loss of $176 \mathrm{Da}$, indicating that they may be the glucuronide conjugates of liquiritigenin and isoliquiritigenin. However, the corresponding retention times differed markedly. According to the literature (23), the present study tentatively identified M17 and M18 as liquiritigenin-4'-O-glucuronide and liquiritigenin-7-O-glucuronide, respectively; and another three metabolites were identified as the glucuronide conjugates of isoliquiritigenin. Further investigation is required to determine the detailed structure of the metabolites of isoliquiritigenin.
Based on the characteristic neutral loss of $80 \mathrm{Da}$ and previous information (28), M31 and M32 were tentatively identified as liquiritigenin-4-O-sulfate and liquiritigenin-7-O-sulfate, respectively.

M7 exhibited the [M-H] $]^{-}$ion at $593 \mathrm{~m} / \mathrm{z}$, which further lost a glucuronic acid moiety $(176 \mathrm{Da})$ to produce the ion at $417 \mathrm{~m} / \mathrm{z}$ [M-H-176] $]^{-}$and $255 \mathrm{~m} / \mathrm{z}$ [M-H-176-162] $]^{-}$, indicating that M8 was the glucuronide conjugate of liquiritin. M38 exhibited the $[\mathrm{M}-\mathrm{H}]^{-}$ion at $433 \mathrm{~m} / \mathrm{z}$ and the further product ion at $257 \mathrm{~m} / \mathrm{z}$ [M-H-176] $]^{-}$and $175 \mathrm{~m} / \mathrm{z}$, suggesting it to be the glucuronide conjugate of davidigenin.

Formononetin has been well documented to be metabolized to daidzein (29), which is $14 \mathrm{Da}\left(\mathrm{CH}_{2}\right)$ less than the protonated ion of formononetin. In the present study, daidzein was then conjugated with methylate, hydroxylate, sulfate and glucuronidate. M13 and M42 exhibited the $[\mathrm{M}-\mathrm{H}]^{-}$ion at $459 \mathrm{~m} / \mathrm{z}$, the $\mathrm{MS}^{2}$ ion at $283 \mathrm{~m} / \mathrm{z}$ and the $\mathrm{MS}^{3}$ ion at $267 \mathrm{~m} / \mathrm{z}$, with a loss of $16 \mathrm{Da}$, compared with the $\mathrm{MS}^{2}$ ion. The $\mathrm{MS}^{2}$ ion was $176 \mathrm{Da}$ less than the protonated ion of M13 and M42. Therefore, M13/M42 was assigned as formononetin hydroxylate glucuronide or its isomer. M43 and M48 had the same neutral loss of $80 \mathrm{Da}$ in the negative ion mass spectrum, indicating that they were the sulfated conjugates of formononetin or isomers. M15 and M34 were identified as glucuronide conjugates due to the characteristic neutral loss of $176 \mathrm{Da}$ (glucuronic acid). The MS2 ion at $311 \mathrm{~m} / \mathrm{z}$ of M15 and the MS ${ }^{2}$ ion at $297 \mathrm{~m} / \mathrm{z}$ of M34 were 44 and 30 Da higher, compared with the weight of formononetin, respectively, indicating that M15 and M34 may be formononetin or daidzein following methylation and hydroxylation. Therefore, M15 and M34 were identified as di-methyl-formononetin hydroxylate glucuronide and methyl formononetin hydroxylate glucuronide, respectively. The possible metabolic pathways of the formononetin-associated compounds are presented in Fig. 6.

M16 and M27 produced fragment ions at 529 and $353 \mathrm{~m} / \mathrm{z}$, corresponding to a loss of $176 \mathrm{Da}$. Therefore, they were tentatively identified as glucuronide conjugates of licoisoflavone A. M45 exhibited the $[\mathrm{M}-\mathrm{H}]^{-}$ion at $515 \mathrm{~m} / \mathrm{z}$ and the product ion at $353 \mathrm{~m} / \mathrm{z}$ with a loss of $162 \mathrm{Da}$ (glucose- $\mathrm{H}_{2} \mathrm{O}$ ). Thus, M45 was identified as licoisoflavone A glucose.

M24 exhibited the $[\mathrm{M}-\mathrm{H}]^{-}$ion at $579 \mathrm{~m} / \mathrm{z}$, and M22 and M29 exhibited the [M-H] $]^{-}$ion at $447 \mathrm{~m} / \mathrm{z}$; and they exhibited the same fragment ion, at 271 and $151 \mathrm{~m} / \mathrm{z}$, as naringenin. Their MS/MS spectra produced the [M-H-308] ion at $271 \mathrm{~m} / \mathrm{z}$ of M24, and the [M-H-176] $]^{-}$ion at $271 \mathrm{~m} / \mathrm{z}$ of M22 and M29. Therefore, M24 was tentatively identified as naringenin-7-rutinoside, and M22, M29 was tentatively identified as naringenin-7-O-glucuronide or naringenin-4'-O-glucuronide. M30 exhibited the $[\mathrm{M}-\mathrm{H}]^{-}$ion at $609 \mathrm{~m} / \mathrm{z}$, the $\mathrm{MS}^{2}$ ion [M-H-308] $]^{-}$ion at $301 \mathrm{~m} / \mathrm{z}$ and the $\mathrm{MS}^{3}$ ion [M-H-308- $\left.\mathrm{CH}_{3}\right]^{-}$ion at $286 \mathrm{~m} / \mathrm{z}$, which were consistent with previous reports (30). Therefore, M30 was tentatively identified as hesperidin. M48 exhibited the $[\mathrm{M}-\mathrm{H}]^{-}$ion at $349 \mathrm{~m} / \mathrm{z}$, the $\left[\mathrm{M}-\mathrm{H}-\mathrm{CH}_{2} \mathrm{O}_{2}\right]^{-}$ion at $303 \mathrm{~m} / \mathrm{z}$ in the $\mathrm{MS}^{2}$ spectrum and the $\left[\mathrm{M}-\mathrm{H}-\mathrm{CH}_{2} \mathrm{O}_{2}-\mathrm{OH}\right]^{-}$ion at $287 \mathrm{~m} / \mathrm{z}$ in the $\mathrm{MS}^{3}$ spectrum, indicating that M48 may be the metabolite of the parent compound, quercetin. As a result, M48 was identified as dihydroxyl methyl quercetin-chalcone.

Identification of saponin-associated metabolites. M40 exhibited an [M-H] $]^{-}$ion at $455 \mathrm{~m} / \mathrm{z}$, which produced a 


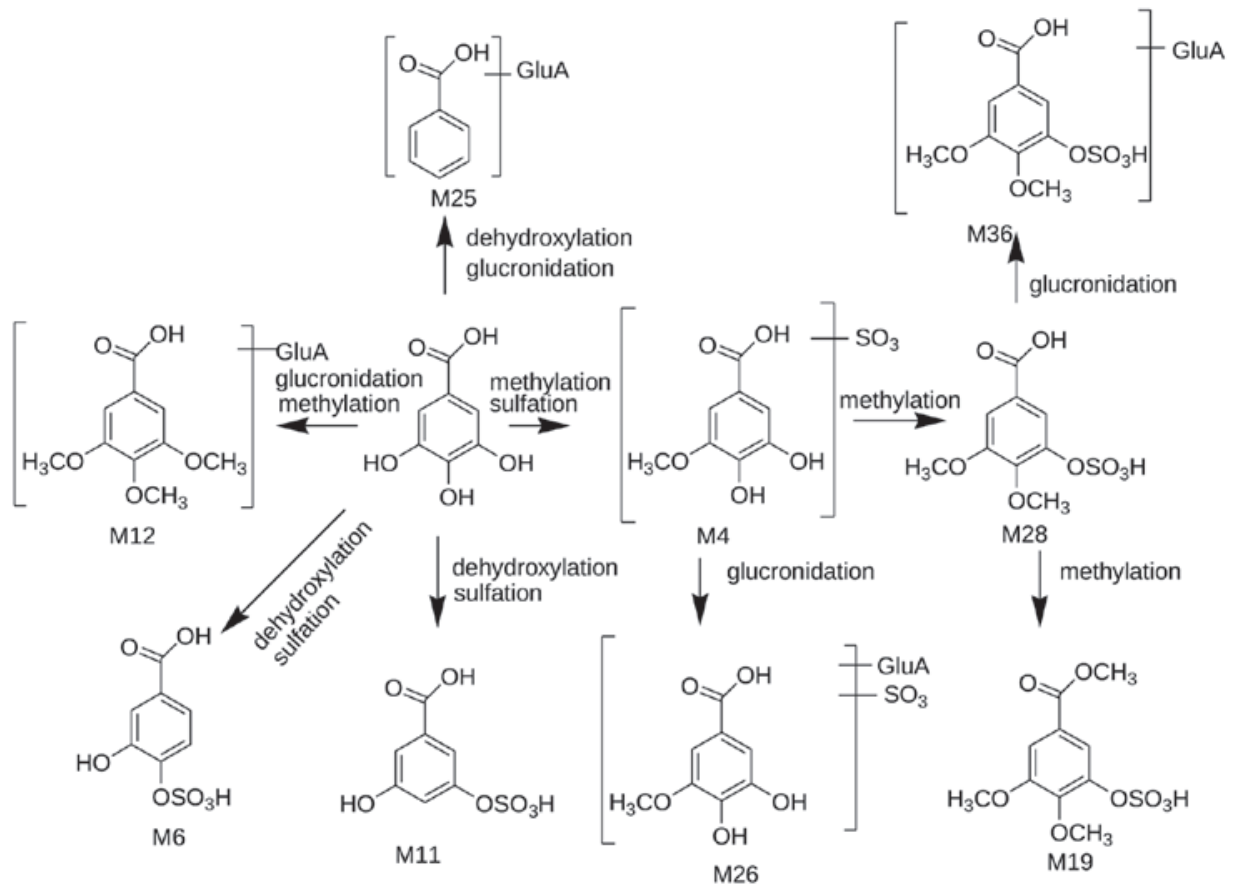

Figure 3. Suggested metabolic pathways of gallic acid-associated metabolites following oral administration with Shu-Yu capsule.

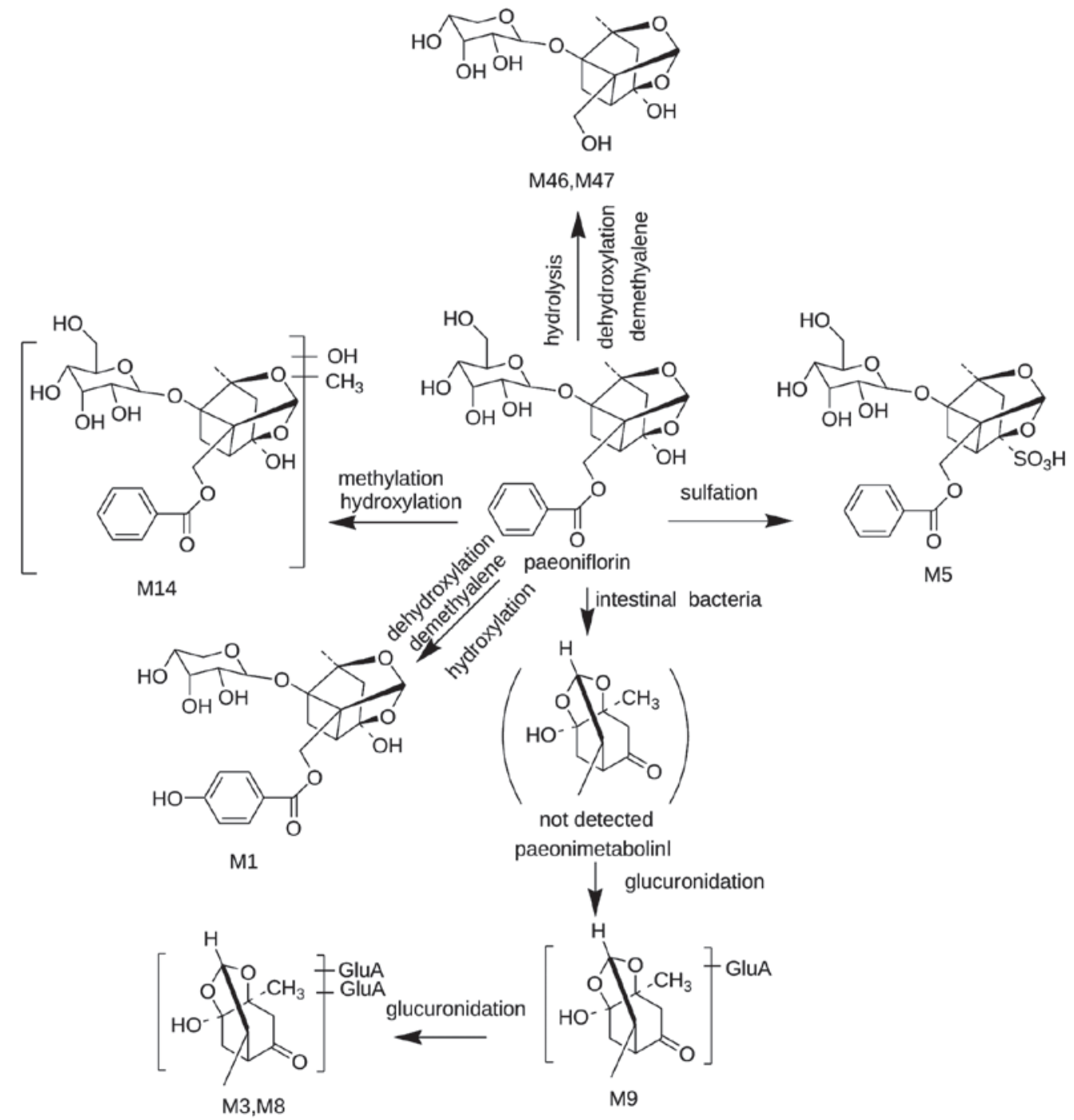

Figure 4. Suggested metabolic pathways of paeoniflorin-associated metabolites following oral administration with Shu-Yu capsule. 
<smiles>COc1ccc(C2CC(=O)c3ccc(O)cc3O2)cc1</smiles>

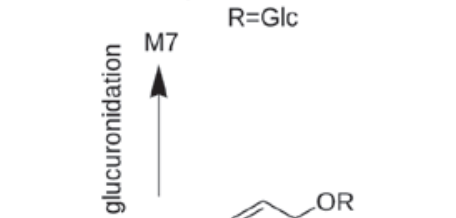<smiles>[R]Oc1ccc(C2CC(=O)c3ccc(O)cc3O2)cc1</smiles>

liquiritin

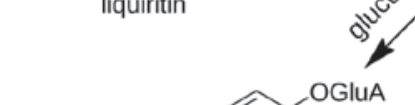<smiles>COc1ccc(C2CC(=O)c3ccc(O)cc3O2)cc1</smiles>

M17<smiles>[R20]Oc1ccc([C@H]2CC(=O)c3ccc(O[R20])cc3O2)cc1</smiles><smiles>COc1ccc(O)c(C=CC(=O)c2ccc(O)cc2O)c1</smiles>

M20,M21,M35

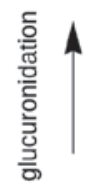

\section{帝}

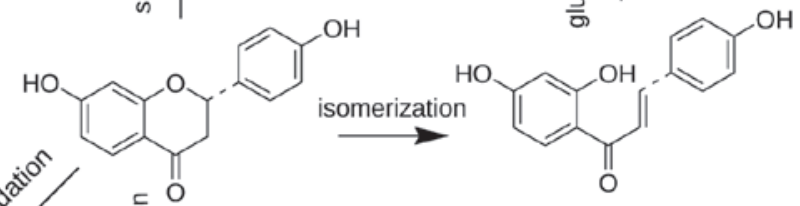

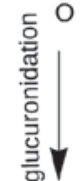<smiles>CC(C)Oc1ccc2c(c1)OC(c1ccc(O)cc1)CC2=O</smiles>

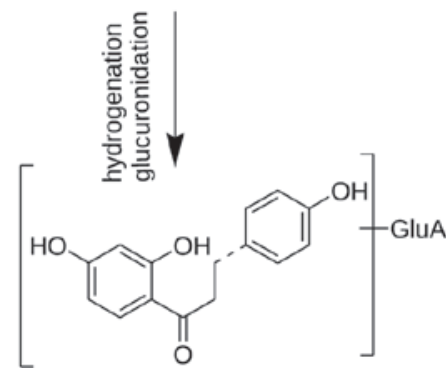

M18

Figure 5. Suggested metabolic pathway of liquiritin following oral administration with Shu-Yu capsule.

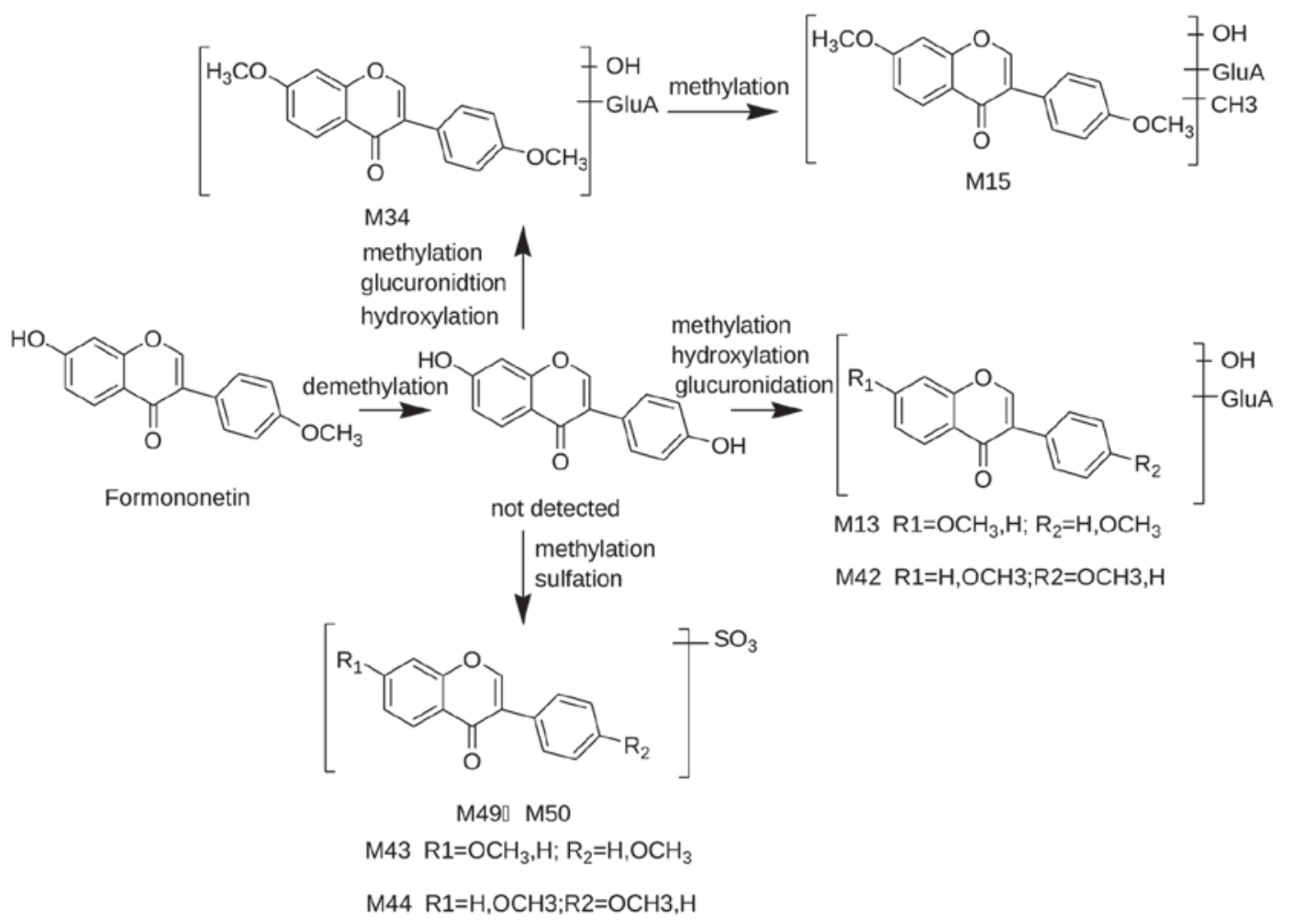

Figure 6. Suggested metabolic pathways of formononetin following oral administration with Shu-Yu capsule.

product ion at $437 \mathrm{~m} / \mathrm{z}$ with a loss of $18 \mathrm{Da}$. Consistent with the literature (20), the heteroannular and the homoannular saikogenins showed different characteristic fragment ions of the deprotonated molecules, including the ions $\left[\mathrm{M}-\mathrm{H}-\mathrm{H}_{2} \mathrm{O}\right]^{-}$, $\left[\mathrm{M}-\mathrm{H}-\mathrm{CH}_{3} \mathrm{OH}\right]^{-}$or $\left[\mathrm{M}-\mathrm{H}-\mathrm{CH}_{2} \mathrm{O}-\mathrm{H}_{2} \mathrm{O}\right]^{-}$. In addition, the fragmentations observed at $\left[\mathrm{M}-\mathrm{H}-\mathrm{H}_{2} \mathrm{O}\right]^{-}$were most abundant for 
SGH $(471 \mathrm{~m} / \mathrm{z})$ and SGB $(455 \mathrm{~m} / \mathrm{z}),\left[\mathrm{M}-\mathrm{H}-\mathrm{CH}_{3} \mathrm{OH}\right]^{-}$for SGD $(471 \mathrm{~m} / \mathrm{z})$ and $\left[\mathrm{M}-\mathrm{H}-\mathrm{CH}_{2} \mathrm{O}-\mathrm{H}_{2} \mathrm{O}\right]$ for SGA $(471 \mathrm{~m} / \mathrm{z})$ and SGC $(455 \mathrm{~m} / \mathrm{z})$ in the negative ion MS/MS spectra. Therefore, the M40 metabolite was characterized as SGB.

Identification of coumarin-associated metabolites. M41 produced a $[\mathrm{M}-\mathrm{H}]^{-}$ion at $559 \mathrm{~m} / \mathrm{z}$, which produced a product ion at $383 \mathrm{~m} / \mathrm{z}$ with a loss of $176 \mathrm{Da}$, indicating that M41 was a glucuronide conjugate. In addition, the product ion at $383 \mathrm{~m} / \mathrm{z}$ was $16 \mathrm{Da}$ higher, compared with that of the molecular weight of glycycoumarin, which was tentatively assigned to hydroxylation reactions of glycycoumarin. Thus, M41 was identified as glycycoumarin hydroxylate glucuronide, which corroborates results from the literature (31).

M49 yielded a [M-H] ion at $447 \mathrm{~m} / \mathrm{z}$, which produced a product ion at $367 \mathrm{~m} / \mathrm{z}$ with a loss of $80 \mathrm{Da}\left(\mathrm{SO}_{3}\right)$, indicating that M49 was a sulfate conjugate of glycycoumarin, according to the literature (31). Thus, M49 was tentatively identified as glycycoumarin sulfate.

\section{Discussion}

In the present study, an HPLC-ESI-MS ${ }^{\mathrm{n}}$ method was developed and applied to analyze the herbal components of SYC extracts, and the absorbed compounds and metabolites in rat serum following oral administration of SYC extracts. As a result, a total of 73 herbal components, including 28 monoterpenes, 26 flavonoids, 9 triterpenoids, 2 coumarins, and other phenolic compounds and galloyl glucoses were observed and tentatively identified. All the MS ${ }^{\mathrm{n}}$ data from these compounds in SYC were consistent with previous literature for every herb $(10,18)$. The compounds identified from the formulation provided information to support further investigation on the absorbed components and metabolites of SYC in rat serum.

The absorbed components and metabolites identified in the present study provide an overall understanding of the absorption and metabolism of SYC in the rat body. Flavonoids were the most abundant metabolites in the drug-containing serum, and a total of 28 flavonoids, including five parent compounds and 23 metabolites, were identified in the drug-containing serum. Monoterpene glycoside compounds were found to be another primary absorbed component, including seven parent compounds and eight metabolites in the dosed serum were found. A total of eight metabolites were produced from gallic acid-related compounds and two metabolites were produced from the coumarin derivates. These results revealed that certain flavonoid glycosides and monoterpene glycosides were absorbed directly. Glucuronidation and sulfation were the predominant metabolic pathways of the components in SYC. In addition, it appeared that certain phase I reactions, including hydrolysis, demethylation and hydroxylation, also occurred.

Saponins are important in SYC, particularly the SSs, which were characterized with poor oral bioavailability. The majority of the SSs contained the unstable XIII, 28-oxide linkage, which may be hydrolyzed during extraction by organic acid or upon heating (32). Therefore, SSs exert curative effects by sequential deglycosylation metabolism in the intestine to form secondary glycoside and aglycones with improved pharmacological effects.
As is already known, TCM contains complex chemical constituents, which are directly absorbed into the blood, or indirectly absorbed via digestive intake or liver metabolism, and are then transported to target tissue through the circulation and exert effects on target tissue. The complexity and diversity of parent compounds and metabolites in the serum following the administration of TCM conforms to the theory of integrity and the synergistic effect of TCM, which is the material basis of the pharmacological actions. However, further investigations are required to clarify such pharmacological actions.

A simple and economical HPLC-ESI-MS ${ }^{\mathrm{n}}$ method was established in the present study, and led to the first report, to the best of our knowledge, on the comprehensive determination of chemical constituents in SYC, as well as its metabolites in rat serum. The results of the present study provide a basis and theoretical foundation for clarification of the chemical composition and potential bioactive compounds of SYC. The results of the present study provided useful information for the further investigation of the pharmacology and mechanism of action of SYC.

\section{Acknowledgements}

This study was supported by a grant from the 973 Program of China (grant no. 2011CB-505100).

\section{References}

1. Gao X, Sun P, Qiao M, Wei S, Xue L and Zhang H: Shu-Yu capsule, a traditional chinese medicine formulation, attenuates premenstrual syndrome depression induced by chronic stress constraint. Mol Med Rep 10: 2942-2948, 2014.

2. Chen SL and Chen DX: Clinical application of combined use of Radix Bupleuri and Radix Paeoniae Alba. Shanghai Journal of TCM 41: 71-74, 2007 (In Chinese).

3. Mao QQ, Xian YF, Ip SP, Tsai SH and Che CT: Long-term treatment with peony glycosides reverses chronic unpredictable mild stress-induced depressive-like behavior via increasing expression of neurotrophins in rat brain. Behav Brain Res 210: 171-177, 2010.

4. Kwon S, Lee B, Kim M, Lee H, Park HJ and Hahm DH: Antidepressant-like effect of the methanolic extract from Bupleurum falcatum in the tail suspension test. Prog Neuropsychopharmacol Biol Psychiatry 34: 265-270, 2010.

5. Su GY, Yang JY, Wang F, Ma J, Zhang K, Dong YX, Song SJ, Lu XM and Wu CF: Antidepressant-like effects of xiaochaihutang in a rat model of chronic unpredictable mild stress. J Ethnopharmacol 152: 217-226, 2014.

6. Song CH, Li F, Guo YH and Zhang HY: Effects of Shuyu capsule and its main composition on protein expression and function of CACNA1C in hippocampus of rat with PMS liver-qi stagnation. Chinese Pharmacological Bulletin 30: 1476-1477, 2014 (In Chinese).

7. Wang XJ, Sun WJ, Sun H, Lv H, Wu Z, Wang P, Liu L and $\mathrm{Cao} \mathrm{H}$ : Analysis of the constituents in the rat plasma after oral administration of Yin Chen Hao Tang by UPLC/Q-TOF-MS/MS J Pharm Biomed Anal 46: 477-490, 2008.

8. Ge QF. Effects of ShuYu capsule on the expression of 5-HT3 receptor and its signal pathway of 5-HTR3-Ca2 $2^{+}-\mathrm{CaM}$ in rat hippocampus neurons. Master's degree thesis of Shandong University of Traditional Chinese Medicine: 32-33, 2012 (In Chinese).

9. National Research Council. Guide for the Care and Use of Laboratory Animals. Washington, DC: The National Academies Press, 1996. doi:10.17226/5140.

10. Li SL, Song JZ, Choi FF, Qiao CF, Zhou Y, Han QB and $\mathrm{Xu}$ HX: Chemical profiling of Radix Paeoniae evaluated by ultra-performance liquid chromatography/photo-diode-array/quadrupole time-of-flight mass spectrometry. J Pharm Biomed Anal 49: 253-266, 2009. 
11. Braca A,Kiem PV, Yen PH, Nhiem NX, Quang TH, Cuong NX and Minh CV: New monoterpene glycosides from Paeonia lactiflora. Fitoterapia 79:117-120, 2008.

12. Lin HC; Ding HY, TW TS and Wu PL: Monoterpene glycosides from Paeonia suffruticosa. Phytochemistry 41: 237-242, 1996.

13. Su J, Zhang P, Zhang JJ, Qi XM, Wu YG and Shen JJ: Effects of total glucosides of paeony on oxidative stress in the kidney from diabetic rats. Phytomedicine 17: 254-260, 2010.

14. Liang J, Xu F, Zhang YZ, Huang S, Zang XY, Zhao X, Zhang L, Shang MY, Yang DH, Wang X and Cai SQ: The profiling and identification of the absorbed constituents and metabolites of Paeoniae Radix Rubra decoction in rat plasma and urine by the HPLC-DAD-ESI-IT-TOF-MS(n) technique: A novel strategy for the systematic screening and identification of absorbed constituents and metabolites from traditional Chinese medicines. J Pharm Biomed Anal 83: 108-121, 2013.

15. Xiao S, Luo K, Wen X, Fan X and Cheng Y: A pre-classification strategy for identification of compounds in traditional Chinese medicine analogous formulas by high-performance liquid chromatography-Mass spectrometry. J Pharm Biomed Anal 92: 82-89, 2014

16. Yang YY, Tang YZ, Fan CL, Luo HT, Guo PR and Chen JX: Identification and determination of the saikosaponins in Radix bupleuri by accelerated solvent extraction combined with rapid-resolution LC-MS. J Sep Sci 33: 1933-1945, 2010.

17. Chen L, Qi J, Chang YX,Zhu D and Yu B: Identification and determination of the major constituents in Traditional Chinese Medicinal formula Danggui-Shaoyao-San by HPLC-DAD-ESI-MS/MS. J Pharm Biomed Anal 50: 127-137, 2009.

18. Wang DD, Liang J, Yang WZ, Hou JJ, Yang M, Da J, Wang Y, Jiang BH, Liu X, Wu WY and Guo DA: HPLC/q TOF-MS-oriented characteristic components data set and chemometric analysis for the holistic quality control of complex TCM preparations: Niuhuang Shangqing pill as an example. J Pharm Biomed Anal 89: 130-141, 2014

19. Bao Y, Li C, Shen H and Nan F: Determination of saikosaponin derivatives in Radix bupleuri and in pharmaceuticals of the chinese multiherb remedy xiaochaihu-tang using liquid chromatographic tandem mass spectrometry. Anal Chem 76: 4208-4216, 2004.

20. Liang Z, Oh K, Wang Y, Yi T, Chen H and Zhao Z: Cell type-specific qualitative and quantitative analysis of saikosaponins in three Bupleurum species using laser microdissection and liquid chromatography-quadrupole/time of flight-mass spectrometry. J Pharm Biomed Anal 97: 157-165, 2014

21. Yan Y, Chai CZ, Wang DW, Yue XY, Zhu DN and Yu BY: HPLC-DAD-Q-TOF-MS/MS analysis and HPLC quantitation of chemical constituents in traditional Chinese medicinal formula Ge-Gen decoction. J Pharm Biomed Anal 80: 192-202, 2013.
22. Wang S, Chen L, Leng J, Chen P, Fan X and Cheng Y: Fragment ion diagnostic strategies for the comprehensive identification of chemical profile of Gui-Zhi-Tang by integrating high-resolution MS, multiple-stage MS and UV information. J Pharm Biomed Anal 98: 22-35, 2014.

23. Yan Z, Chen Y, Li T, Zhang J and Yang X: Identification of metabolites of Si-Ni-San, a traditional Chinese medicine formula, in rat plasma and urine using liquid chromatography/diode array detection/triple-quadrupole spectrometry. J Chromatogr B Analyt Technol Biomed Life Sci 885-886: 73-82, 2012.

24. Wang Y, He S, Cheng X, Lu Y, Zou Y and Zhang Q: UPLC-Q-TOF-MS/MS fingerprinting of traditional Chinese formula SiJunZiTang. J Pharm Biomed Anal 80: 24-33, 2013.

25. Xiang C, Qiao X, Ye M and Guo DA: Classification and distribution analysis of compounds in Glycyrrhiza using licorice compounds database. Yao Xue Xue Bao 47: 1023-1030, 2012 (In Chinese).

26. Zhang W, Saif MW, Dutschman GE, Li X, Lam W, Bussom S, Jiang Z, Ye M, Chu E and Cheng YC: Identification of chemicals and their metabolites from PHY906, a Chinese medicine formulation, in the plasma of a patient treated with irinotecan and PHY906 using liquid chromatography/tandem mass spectrometry (LC/MS/MS). J Chromatogr A 1217: 5785-5793, 2010.

27. Holcapek M,Kolárová L and Nobilis M: High-performance liquid chromatography-tandem mass spectrometry in the identification and determination of phase I and phase II drug metabolites. Anal Bioanal Chem 391: 59-78, 2008.

28. Lu LL, Shu Y, Qian DW, Su SL, Duan JA, Qian YF and Xue CF: Identification of the metabolites of Sinisan extract in rat plasma, urine, feces and bile after intragastric administration. Acta Pharm Sin 46: 1374-1379, 2011 (In Chinese).

29. Tolleson WH, Doerge DR, Churchwell MI, Marques MM and Roberts DW: Metabolism of biochanin A and formononetin by human liver microsomes in vitro. J Agric Food Chem 50: 4783-4790, 2002.

30. Su ZH, Zou GA, Preiss A, Zhang HW and Zou ZM: Online identification of the antioxidant constituents of traditional Chinese medicine formula Chaihu-Shu-Gan-San by LC-LTQ-Orbitrap mass spectrometry and microplate spectrophotometer. J Pharm Biomed Anal 53: 454-461, 2010.

31. Qiao X, Ye M, Xiang C, Wang Q, Liu CF, Miao WJ and Guo DA: Analytical strategy to reveal the in vivo process of multi-component herbal medicine: A pharmacokinetic study of licorice using liquid chromatography coupled with triple quadrupole mass spectrometry. J Chromatogr A 1258: 84-93, 2012.

32. Huang HQ, Zhang X, Xu ZX, Su J, Yan SK and Zhang WD: Fast determination of saikosaponins in Bupleurum by rapid resolution liquid chromatography with evaporative light scattering detection. J Pharm Biomed Anal 49: 1048-1055, 2009. 